\title{
Improving photosynthesis to increase grain yield potential: an analysis of maize hybrids released in different years in China
}

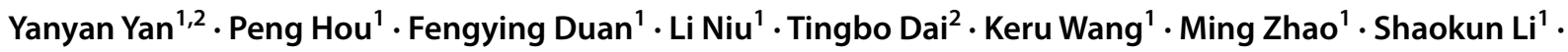 \\ Wenbin Zhou' ${ }^{1}$ (1)
}

Received: 29 January 2021 / Accepted: 11 May 2021 / Published online: 25 May 2021

(c) The Author(s) 2021

\begin{abstract}
In this work, we sought to understand how breeding has affected photosynthesis and to identify key photosynthetic indices that are important for increasing maize yield in the field. Our 2-year (2017-2018) field experiment used five high-yielding hybrid maize cultivars (generated in the 1970s, 2000s, and 2010s) and was conducted in the Xinjiang Autonomous Region of China. We investigated the effects of planting density on maize grain yield, photosynthetic parameters, respiration, and chlorophyll content, under three planting density regimens: 75,000, 105,000, and 135,000 plants ha ${ }^{-1}$. Our results showed that increasing planting density to the medium level $\left(105,000\right.$ plants $\left.\mathrm{ha}^{-1}\right)$ significantly increased grain yield (Y) up to $20.32 \%$ compared to the low level $\left(75,000\right.$ plants ha $\left.{ }^{-1}\right)$. However, further increasing planting density to 135,000 plants ha $^{-1}$ did not lead to an additional increase in yield, with some cultivars actually exhibiting an opposite trend. Interestingly, no significant changes in photosynthetic rate, dark respiration, stomatal density, and aperture were observed upon increasing planting density. Moreover, our experiments revealed a positive correlation between grain yield and the net photosynthetic rate $\left(\mathrm{P}_{\mathrm{n}}\right)$ upon the hybrid release year. Compared to other cultivars, the higher grain yield obtained in DH618 resulted from a higher 1000-kernel weight (TKW), which can be explained by a longer photosynthetic duration, a higher chlorophyll content, and a lower ratio of chlorophyll $a / b$. Moreover, we found that a higher leaf area per plant and the leaf area index (HI) do not necessarily result in an improvement in maize yield. Taken together, we demonstrated that higher photosynthetic capacity, longer photosynthetic duration, suitable LAI, and higher chlorophyll content with lower chlorophyll $a / b$ ratio are important factors for obtaining high-yielding maize cultivars and can be used for the improvement of maize crop yield.
\end{abstract}

Keywords Grain yield $\cdot$ Photosynthesis $\cdot$ Density-tolerance $\cdot$ Planting density $\cdot$ Maize

\section{Introduction}

In order to meet the needs of an ever-increasing human population, global crop production rate needs to double by 2050 (2.4\% annual growth rate) (Pradhan et al. 2015). However, the average output of major crops increases by only $0.9-1.6 \%$ per year, which remains far below the required levels (Ray et al. 2013). This puts a significant pressure on global food security and makes the cultivation of high-yielding crops

Wenbin Zhou

zhouwenbin@caas.cn

1 Institute of Crop Sciences, Chinese Academy of Agricultural Sciences, Beijing 100081, China

2 Key Laboratory of Crop Physiology Ecology and Production Management of Ministry of Agriculture, Nanjing Agricultural University, Nanjing 210095, China an agricultural necessity, whereby increasing crop yield potential constitutes a major breeding goal of the modern era (Foley et al. 2011; Evans and Lawson 2020; Phalan et al. 2011; Paz et al. 2020). Maize is a high-yielding $\mathrm{C}_{4}$ grainproducing cereal and the second largest crop in the world, representing a central target for improving total crop production capacity (FAO 2017; Ort and Long 2014). The past decades witnessed significant efforts by maize breeders to consistently increase grain yield (Tollenaar 1989; Niu et al. 2013) despite a recent deacceleration, especially in Europe (Foley et al. 2011). Agronomic management, including the application of fertilizers or increasing plant density, affects breeding strategies and plays an important role in the attempt to improve crop yield ( $\mathrm{Lu}$ and Tian 2017; Mansfield and Mumm 2014). In the specific case of maize, crop production has reached a plateau in several countries, as indicated by little changes in maize grain yield per unit area in China 
(Gong et al. 2015; Ray et al. 2012). Based on a meta-analysis of 140 published results, Slattery et al. found that fertilizer supply, $\mathrm{CO}_{2}$ concentration, and shading have a significant influence on crop yield. Hence, improving photosynthesis can help increasing yield (Slattery et al. 2013). Moreover, and considering that (1) traditional breeding and selection did not focus on photosynthetic efficiency and (2) that $\mathrm{CO}_{2}$ concentration is predicted to increase as a result of global climate change, it is necessary to better understand photosynthesis in order to continuously increase yield potential (Long et al. 2006; Raines 2011; Zhu et al. 2010).

A few studies aiming to elevate crop yield have already attempted to manipulate photosynthetic efficiency (Parry et al. 2011; Wang et al. 2018; Li et al. 2020), and previous results suggested that increased grain yield can be achieved by increasing leaf area and the absorption of radiation (Testa et al. 2016; Meena et al. 2021). Furthermore, it has been shown that increasing plant density significantly enhances maize grain yield due to a higher capture efficiency of photosynthetically active radiation and light energy use, improving the photosynthetic capacity of the canopy (Zhang et al. 2014). In fact, a positive correlation between the photosynthetic rate at the canopy level and the productivity of individual plants has been reported across different crops, including $\mathrm{C}_{3}$ plants such as wheat, barley, or soybean (Reynolds et al. 2000; Carmo-Silva et al. 2017; Biscoe et al. 1975; Wells et al. 1982), and $\mathrm{C}_{4}$ plants including maize and sorghum (Vietor and Musgrave 1979; Peng et al. 1991). However, these results have been challenged and the increase in photosynthetic rates is regarded as slight and not significantly contributing to changes in crop biomass and yield (Chytyk et al. 2011; Sadras et al. 2012; Wu et al. 2019; Leakey et al. 2019). According to Zelitch (1982), the perceived lack of relationship between photosynthesis and production results from an instantaneous measurement of photosynthetic activity at improper developmental stages. Moreover, the experimental conditions in the laboratory do not necessarily reflect natural conditions in the field, and variation at the genetic level might impact photosynthetic efficiency (Reynolds et al. 2000; Zelitch 1982) In summary, the relationship between leaf photosynthesis and yield remains controversial (Sinclair et al. 2019).

The goal of this study was to determine whether maize varieties released in different years show differences in photosynthetic capacity. Furthermore, we aimed at understanding to what extent the ear leaf photosynthesis reflects differences in yield across distinct cultivars. Our research was conducted in the Xinjiang Uygur Autonomous Region, where sufficient sun light, radiation, and a large diurnal temperature range represent adequate environmental factors that allow for the cultivation of high-yield maize crops. In the present study, five maize hybrids released in different years which had created highest yield in China were used to evaluate the role of photosynthesis in determining maize grain yield. To achieve this, we systematically measured maize yield components, leaf area, photosynthetic parameters (including chlorophyll amount), and stomatal status in the maize hybrids grown under different planting densities. In addition, we analyzed the ratio of red to far-red light at the ear position, the chlorophyll fluorescence at $77 \mathrm{~K}$, and the accumulation of biomass, to investigate the physiological mechanisms underlying the production of high-yield maize mediated by photosynthetic activity.

\section{Materials and methods}

\section{Experimental location and environmental conditions}

The field experiments were conducted at Qitai farm $\left(89^{\circ} 34^{\prime}\right.$ $\mathrm{E}, 44^{\circ} 12^{\prime} \mathrm{N}$ ) during the growing season (April to October) in 2017 and 2018. The experimental site was located in the Xinjiang Uygur Autonomous Region, which is situated in northwestern China, an irrigated spring maize region with an arid continental climate. The annual average precipitation and solar radiation in this region are approximately $269.4 \mathrm{~mm}$ and $14.4 \mathrm{MJ} \mathrm{m}^{2} \mathrm{day}^{-1}$. The mean daily maximum temperature, minimum temperature, and diurnal temperature variation are $13.9{ }^{\circ} \mathrm{C},-0.8{ }^{\circ} \mathrm{C}$, and $14.9{ }^{\circ} \mathrm{C}$, respectively. The climatic conditions of 2017 and 2018 during the maize growing season are shown in Fig. 1. During the growing season, the mean daily maximum temperature, the mean daily minimum temperature, and the mean daily temperature were $25.6{ }^{\circ} \mathrm{C}, 12.8^{\circ} \mathrm{C}$, and $19.1^{\circ} \mathrm{C}$ in 2017 , and $24.3^{\circ} \mathrm{C}, 10.6^{\circ} \mathrm{C}$, and $17.3^{\circ} \mathrm{C}$ in 2018 . In 2017 and 2018, the total radiation was $4521.9 \mathrm{MJ} \mathrm{m}^{-2}$ and $4686.7 \mathrm{MJ} \mathrm{m}^{-2}$, and the total precipitation was $175.2 \mathrm{~mm}$ and $221.0 \mathrm{~mm}$, respectively.

We used five different maize cultivars in this study, including Zhengdan 958 (ZD958), Xianyu 335 (XY335), Denghai 618 (DH618), Liangyu 66 (LY66), and SC704. The maize hybrids were released at different times over the previous decades (SC670 in 1970s; ZD958, XY335 and LY66 in 2000s; DH618 in 2010s), and each had the highest yield at the Qitai farm in different years (see Table S1). Each cultivar was planted at three planting densities: 75,000 plants ha ${ }^{-1}$ (low density, L), 105,000 plants ha ${ }^{-1}$ (medium density, M) and 135,000 plants ha ${ }^{-1}$ (high density, H). The low density is recommended for most parts of China (Ming et al. 2017; Hou et al. 2020), the medium density is associated with higher yield (Yang et al. 2020), and the high density has been adopted in highyield experiments (Liu et al. 2017, 2020). We employed similar treatments to the plants in 2017 and 2018. However, there was an unexpected snow at the seedling stage in 2018, resulting in a relatively lower actual density when 


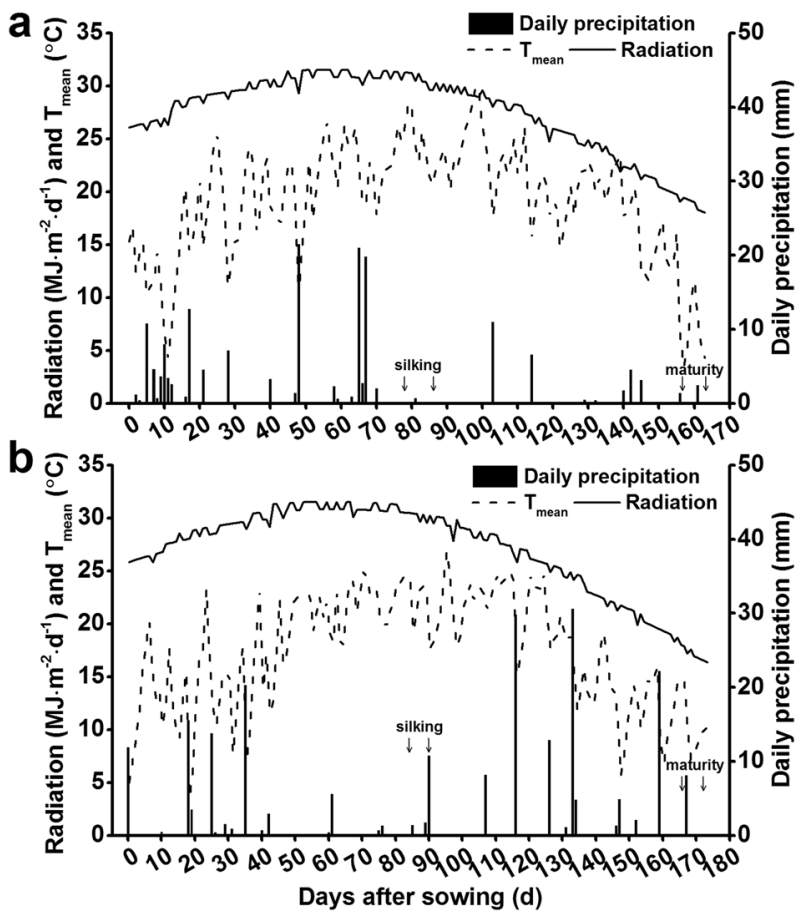

Fig. 1 Radiation (MJ $\mathrm{m}^{-2}$ day $^{-1}$ ), daily mean temperature $\left(\mathrm{T}_{\text {mean }},{ }^{\circ} \mathrm{C}\right)$, and daily precipitation $(\mathrm{mm})$ during the growth period of maize in 2017 (a) and 2018 (b). The data range of the silking and filling stages includes five varieties that were marked with arrow lines

compared to 2017. Hence, we only used the plots which have proper plant density for downstream experiments. The actual planting density at harvest is shown in Tables 1 and 2. Maize seeds were sown by hand on April 21 and 17 , and plants were harvested on October 1 and 14, in the years 2017 and 2018, respectively. In each year, the experimental treatments were arranged in a split-split plot design, where the density and the cultivars were set as the main plot and subplot, respectively, with three experimental replicates performed per treatment. In order to match the local cultivation practices, the plots were set up in a narrow-wide row planting pattern, which consisted of alternating rows 0.4 and $0.6 \mathrm{~m}$ apart, with each plot measuring $10 \mathrm{~m}$ long $\times 8 \mathrm{~m}$ wide. The seeds were sown under plastic film with a drip irrigation system to prevent drought stress. Sufficient water and fertilizers were applied to prevent deficient water and nutrient stress. Base fertilizers were applied with $150 \mathrm{~kg} \mathrm{~N} \mathrm{ha}^{-1}$ as urea, $225 \mathrm{~kg} \mathrm{P}_{2} \mathrm{O}_{5}$ $\mathrm{ha}^{-1}$ (super phosphate), and $75 \mathrm{~kg} \mathrm{~K}_{2} \mathrm{O} \mathrm{ha}{ }^{-1}$ (potassium sulfate) prior to sowing. An additional $300 \mathrm{~kg} \mathrm{~N} \mathrm{ha}^{-1}$ was applied during the growing season to prevent nutritional stress. The accumulation of weeds, and the management of diseases and pests were implemented following the protocols of Yang et al. (2019).

\section{Sampling and measurements}

\section{Yield and yield components}

Twenty ears from the center of four rows of each plot were collected and air-dried at physiological maturity to determine the number of kernels per plant and the 1000-kernel weight (TKW). To determine grain yield, plants at physiological maturity were manually harvested from a $12 \mathrm{~m}^{2}$ area in each plot, excluding the border rows. Maize grain and biomass yields were determined at $14 \%$ moisture content and dry weight, respectively.

\section{Dry matter accumulation and leaf area}

The aerial parts of three representative plants from each plot were taken in order to assess the accumulation of dry matter at the silking and maturity stages. The leaf area and the leaf area index were calculated as previously described (Xu et al. 2017). All samples were heat-treated at $105^{\circ} \mathrm{C}$ for $30 \mathrm{~min}$, then dried at $80^{\circ} \mathrm{C}$ to constant weight to allow for an estimation of dry matter accumulation. The harvest index (HI) was calculated as the ratio of grain yield to the total biomass at the maturity stage (Curin et al. 2020).

\section{Gas-exchange measurements}

At the silking, filling, and maturity stages, the ear leaf of three representative maize plants were selected from each plot to measure the net photosynthetic rate $\left(\mathrm{P}_{\mathrm{n}}\right)$, the stomatal conductance $\left(\mathrm{G}_{\mathrm{s}}\right)$, the intercellular $\mathrm{CO}_{2}$ concentration $\left(\mathrm{C}_{\mathrm{i}}\right)$, and the transpiration rate $\left(\mathrm{T}_{\mathrm{r}}\right)$. These measurements were performed using a Li-Cor 6400 gas exchange system (Li-Cor Inc., Lincoln USA) equipped with an LED leaf chamber, with a steady photosynthetic photon flux density (PPFD) of $2000 \mu \mathrm{mol}$ photons $\mathrm{m}^{-2} \mathrm{~s}^{-1}$ from 9:00 to 11:00 am on sunny, cloudless days. To determine dark respiration $\left(R_{\mathrm{d}}\right)$ at night, gas exchange measurements were conducted from 11:00 pm until just before sunrise in the following day. A large leaf cuvette $(2 \mathrm{~cm} \times 6 \mathrm{~cm})$ was used together with the LI-6400 gas analyzer to measure $\mathrm{CO}_{2}$ efflux. To determine dark respiration during the day, the leaves were dark-adapted for at least $30 \mathrm{~min}$ in advance (Niu et al. 2020).

\section{Pigment measurements}

The ear leaves were sampled at the silking, grain filling, and maturity stages. Leaf disks in the middle of the ear leaves (avoiding the midribs) were harvested using a hole puncher (area, $1.327 \mathrm{~cm}^{2}$ ) and frozen at $-80{ }^{\circ} \mathrm{C}$ for pigment determination. The amount of chlorophyll and carotenoids was measured spectrophotometrically, according 
Table 1 Grain yield and yield components, total biomass, and HI of five maize hybrids cultivated under different densities in 2017 and 2018

\begin{tabular}{|c|c|c|c|c|c|c|c|c|}
\hline Year & Cultivar & $\begin{array}{l}\text { Plant density } \\
\left(\text { plant } \cdot \mathrm{m}^{2}\right)\end{array}$ & $\begin{array}{l}\text { Grain Yield } \\
\left(\mathrm{Mg} \cdot \mathrm{ha}^{-1}\right)\end{array}$ & Ear No. $\left(10^{3} \mathrm{ha}^{-1}\right)$ & Kernel No. per ear & $\begin{array}{l}\text { 1000-Kernel weight } \\
(\mathrm{g})\end{array}$ & $\begin{array}{l}\text { Total biomass accu- } \\
\text { mulation }\left(\mathrm{t} \cdot \mathrm{ha}^{-1}\right)\end{array}$ & HI \\
\hline \multirow[t]{19}{*}{2017} & \multirow[t]{3}{*}{ SC704 } & $7.5(\mathrm{~L})$ & $16.53 \pm 0.69 \mathrm{e}$ & $67.45 \pm 5.77 \mathrm{i}$ & $633.87 \pm 22.76 \mathrm{a}$ & $370.25 \pm 16.40 \mathrm{bcde}$ & $31.63 \pm 1.65 \mathrm{ef}$ & $0.523 \pm 0.006 \mathrm{cde}$ \\
\hline & & $10.5(\mathrm{M})$ & $18.21 \pm 1.98 \mathrm{cde}$ & $95.52 \pm 8.10 \mathrm{~g}$ & $571.47 \pm 3.06 \mathrm{c}$ & $346.65 \pm 6.26 \mathrm{def}$ & $34.24 \pm 2.43 \mathrm{cde}$ & $0.531 \pm 0.02 \mathrm{cde}$ \\
\hline & & $13.5(\mathrm{H})$ & $13.46 \pm 0.89 \mathrm{f}$ & $90.75 \pm 6.70 \mathrm{~g}$ & $488.27 \pm 18.48 \mathrm{de}$ & $326.36 \pm 34.83 \mathrm{f}$ & $37.52 \pm 2.63 \mathrm{bcd}$ & $0.359 \pm 0.006 \mathrm{~h}$ \\
\hline & \multirow[t]{3}{*}{ ZD958 } & $7.5(\mathrm{~L})$ & $16.24 \pm 1.60 \mathrm{e}$ & $90.48 \pm 5.02 \mathrm{~g}$ & $474.40 \pm 18.07 \mathrm{de}$ & $381.64 \pm 18.35 \mathrm{bcd}$ & $30.63 \pm 0.67 \mathrm{ef}$ & $0.530 \pm 0.043 \mathrm{cde}$ \\
\hline & & $10.5(\mathrm{M})$ & $18.73 \pm 0.68 \mathrm{~cd}$ & $115.15 \pm 5.55 \mathrm{de}$ & $449.13 \pm 17.50 \mathrm{ef}$ & $364.91 \pm 10.14 \mathrm{cdef}$ & $33.18 \pm 1.26 \mathrm{de}$ & $0.564 \pm 0.002 \mathrm{c}$ \\
\hline & & $13.5(\mathrm{H})$ & $18.88 \pm 1.11 \mathrm{~cd}$ & $140.51 \pm 6.79 \mathrm{a}$ & $421.90 \pm 7.80 \mathrm{f}$ & $342.85 \pm 19.27 \mathrm{def}$ & $34.47 \pm 4.79 \mathrm{cde}$ & $0.552 \pm 0.054 \mathrm{~cd}$ \\
\hline & \multirow[t]{3}{*}{ XY335 } & $7.5(\mathrm{~L})$ & $19.23 \pm 0.63 \mathrm{~cd}$ & $80.45 \pm 3.52 \mathrm{~h}$ & $618.27 \pm 16.54 \mathrm{ab}$ & $400.77 \pm 21.27 b c$ & $37.60 \pm 3.19 \mathrm{abcd}$ & $0.513 \pm 0.027 \mathrm{de}$ \\
\hline & & $10.5(\mathrm{M})$ & $19.63 \pm 1.68 \mathrm{~cd}$ & $105.55 \pm 3.24 \mathrm{f}$ & $511.47 \pm 65.26 \mathrm{~d}$ & $368.73 \pm 19.52 \mathrm{bcde}$ & $42.12 \pm 4.44 \mathrm{a}$ & $0.467 \pm 0.019 f g$ \\
\hline & & $13.5(\mathrm{H})$ & $19.81 \pm 1.61 \mathrm{~cd}$ & $130.38 \pm 2.04 b$ & $418.27 \pm 35.72 f$ & $373.79 \pm 10.63 \mathrm{bcde}$ & $40.19 \pm 3.98 \mathrm{ab}$ & $0.493 \pm 0.009 \mathrm{ef}$ \\
\hline & \multirow[t]{3}{*}{ LY66 } & $7.5(\mathrm{~L})$ & $19.88 \pm 0.76 c$ & $80.25 \pm 2.72 \mathrm{~h}$ & $620.40 \pm 17.01 \mathrm{ab}$ & $406.28 \pm 38.18 \mathrm{ab}$ & $37.43 \pm 0.82 \mathrm{bcd}$ & $0.531 \pm 0.009 \mathrm{cde}$ \\
\hline & & $10.5(\mathrm{M})$ & $23.92 \pm 0.81 \mathrm{a}$ & $105.33 \pm 1.89 \mathrm{f}$ & $577.05 \pm 10.58 \mathrm{bc}$ & $404.40 \pm 15.85 \mathrm{abc}$ & $38.30 \pm 0.14 \mathrm{abc}$ & $0.624 \pm 0.019 b$ \\
\hline & & $13.5(\mathrm{H})$ & $17.66 \pm 0.96 \mathrm{de}$ & $120.18 \pm 5.36 \mathrm{~cd}$ & $448.27 \pm 18.90 \mathrm{ef}$ & $338.26 \pm 26.38 \mathrm{ef}$ & $39.87 \pm 3.04 \mathrm{ab}$ & $0.444 \pm 0.017 \mathrm{~g}$ \\
\hline & \multirow[t]{3}{*}{ DH618 } & $7.5(\mathrm{~L})$ & $19.00 \pm 0.35 \mathrm{~cd}$ & $92.29 \pm 4.39 \mathrm{~g}$ & $485.60 \pm 18.12 \mathrm{de}$ & $441.54 \pm 23.13 \mathrm{a}$ & $27.51 \pm 2.00 \mathrm{f}$ & $0.693 \pm 0.044 \mathrm{a}$ \\
\hline & & $10.5(\mathrm{M})$ & $22.44 \pm 0.93 \mathrm{ab}$ & $109.13 \pm 3.59 \mathrm{ef}$ & $477.87 \pm 13.25 \mathrm{de}$ & $440.49 \pm 12.39 \mathrm{a}$ & $33.21 \pm 1.67 \mathrm{de}$ & $0.676 \pm 0.017 \mathrm{a}$ \\
\hline & & $13.5(\mathrm{H})$ & $21.82 \pm 0.06 \mathrm{~b}$ & $127.77 \pm 1.77 \mathrm{bc}$ & $424.53 \pm 6.52 \mathrm{f}$ & $401.30 \pm 6.94 b c$ & $38.78 \pm 0.89 a b c$ & $0.563 \pm 0.014 \mathrm{c}$ \\
\hline & \multicolumn{8}{|l|}{ ANOVA } \\
\hline & Density (D) & & $20.855^{* *}$ & $252.588 * *$ & $99.854 * *$ & $16.303 * *$ & $17.909 * *$ & $53.955^{* *}$ \\
\hline & Variety (V) & & $28.435^{* *}$ & $51.532 * *$ & $38.839 * *$ & $18.043 * *$ & $16.617 * *$ & $62.212 * *$ \\
\hline & $\mathrm{D} \times \mathrm{V}$ & & $7.095^{* *}$ & $6.171^{* *}$ & $6.048 * *$ & $1.222 \mathrm{~ns}$ & $2.116 \mathrm{~ns}$ & $13.419 * *$ \\
\hline \multirow[t]{14}{*}{2018} & \multirow[t]{2}{*}{ SC704 } & $6.3(\mathrm{~L})$ & $15.60 \pm 1.14 \mathrm{~d}$ & $60.35 \pm 4.21 \mathrm{c}$ & $744.3 \pm 93.60 \mathrm{a}$ & $369.3 \pm 8.59 \mathrm{~d}$ & $24.17 \pm 0.99 \mathrm{e}$ & $0.645 \pm 0.023 b$ \\
\hline & & $11.3(\mathrm{H})$ & $16.91 \pm 1.42 \mathrm{bcd}$ & $92.12 \pm 8.32 \mathrm{a}$ & $555.6 \pm 55.31 \mathrm{cde}$ & $325.8 \pm 7.60 \mathrm{e}$ & $37.31 \pm 4.89 b$ & $0.456 \pm 0.033 \mathrm{fg}$ \\
\hline & \multirow[t]{2}{*}{ ZD958 } & $6.9(\mathrm{~L})$ & $18.65 \pm 0.38 \mathrm{abc}$ & $75.57 \pm 2.52 b$ & $615.7 \pm 40.11$ bcde & $418.4 \pm 16.87 \mathrm{a}$ & $29.94 \pm 1.15 \mathrm{~d}$ & $0.624 \pm 0.033 b c$ \\
\hline & & $9.7(\mathrm{M})$ & $20.31 \pm 2.68 \mathrm{a}$ & $98.04 \pm 2.43 \mathrm{a}$ & $552.1 \pm 65.95 \mathrm{de}$ & $383.5 \pm 17.78 \mathrm{bcd}$ & $27.91 \pm 1.21 \mathrm{de}$ & $0.726 \pm 0.065 a$ \\
\hline & \multirow[t]{2}{*}{ XY335 } & $7.0(\mathrm{~L})$ & $18.10 \pm 1.95 \mathrm{abcd}$ & $68.63 \pm 5.86 b c$ & $663.5 \pm 19.06 b$ & $406.5 \pm 11.29 \mathrm{ab}$ & $36.16 \pm 2.90 \mathrm{~b}$ & $0.500 \pm 0.017 \mathrm{ef}$ \\
\hline & & $11.1(\mathrm{H})$ & $19.43 \pm 2.21 \mathrm{ab}$ & $103.55 \pm 16.03 a$ & $531.5 \pm 16.75 \mathrm{e}$ & $379.7 \pm 16.91 \mathrm{~cd}$ & $46.62 \pm 1.74 a$ & $0.416 \pm 0.034 \mathrm{~g}$ \\
\hline & \multirow[t]{2}{*}{ LY66 } & $4.9(\mathrm{~L})$ & $16.44 \pm 1.52 \mathrm{~cd}$ & $67.63 \pm 5.73 b c$ & $640.0 \pm 33.26 b c$ & $417.2 \pm 19.58 \mathrm{a}$ & $31.21 \pm 1.67 \mathrm{~cd}$ & $0.526 \pm 0.024 \mathrm{e}$ \\
\hline & & $7.9(\mathrm{M})$ & $18.18 \pm 1.14 \mathrm{abcd}$ & $76.35 \pm 5.16 b$ & $617.7 \pm 8.05 \mathrm{bcd}$ & $398.4 \pm 4.12 \mathrm{abc}$ & $35.39 \pm 3.98 b$ & $0.516 \pm 0.028 \mathrm{e}$ \\
\hline & \multirow[t]{2}{*}{ DH618 } & $7.5(\mathrm{~L})$ & $19.34 \pm 1.02 \mathrm{ab}$ & $75.86 \pm 3.26 b$ & $626.3 \pm 20.10 \mathrm{bcd}$ & $416.4 \pm 5.99 \mathrm{a}$ & $35.92 \pm 1.92 b$ & $0.538 \pm 0.009 \mathrm{de}$ \\
\hline & & $9.9(\mathrm{M})$ & $20.02 \pm 1.04 \mathrm{a}$ & $94.05 \pm 3.71 \mathrm{a}$ & $556.1 \pm 33.13 \mathrm{cde}$ & $390.1 \pm 14.43 \mathrm{bcd}$ & $34.03 \pm 1.81 \mathrm{bc}$ & $0.589 \pm 0.025 \mathrm{~cd}$ \\
\hline & \multicolumn{8}{|l|}{ ANOVA } \\
\hline & Density (D) & & $6.69 *$ & $90.824 * *$ & $33.904 * *$ & $34.123 * *$ & $34.022 * *$ & $5.329 *$ \\
\hline & Variety (V) & & $6.392 * *$ & $6.026^{* *}$ & $2.343 \mathrm{~ns}$ & $18.296^{* *}$ & $27.59^{* *}$ & $38.847 * *$ \\
\hline & $\mathrm{D} \times \mathrm{V}$ & & $0.129 \mathrm{~ns}$ & $3.759^{*}$ & $3.178 *$ & $0.668 \mathrm{~ns}$ & $14.453 * *$ & $20.382 * *$ \\
\hline
\end{tabular}

Maize plants suffered from cold damage at the seedling stage, resulting in a relatively lower actual density in 2018 . The mean values indicated within a column and the same site followed by different letters denote significant differences at $p<0.05$. L indicates plant density $\leq 7.5$ plants $\mathrm{m}^{-2}$. M denotes plant density $>7.5$ and $\leq 10.5$ plants $\mathrm{m}^{-2}$. $\mathrm{H}$ denotes plant density $>10.5$ plants $\mathrm{m}^{-2}$. The numbers shown in the ANOVA section represent the $\mathrm{F}$ values. ns Not significant; * Significant at the 0.05 probability level; ** Significant at the 0.01 probability level; *** Significant at the 0.001 probability level

to a previously published protocol (Lichtenthaler 1987). Briefly, milled leaf disks were incubated with $1 \mathrm{ml} 100 \%$ acetone at $4{ }^{\circ} \mathrm{C}$ until the pigments were completely extracted. The mixture was then centrifuged at $10,000 \times g$ $\left(4{ }^{\circ} \mathrm{C}\right)$ for $10 \mathrm{~min}$, and the supernatants analyzed with a dual-beam spectrophotometer (Ultrospec 8000PC, Biochrom Ltd., Cambridge, England). All experimental procedures were conducted under low light conditions, and the samples were covered in order to minimize the degradation of chlorophyll as a result of light exposure. A total of three biological replicates were performed for each treatment.

\section{Chlorophyll fluorescence at $77 \mathrm{~K}$}

For the $77 \mathrm{~K}$ measurements, leaf disks from the ear leaves (avoiding the midribs) were homogenized in solution ( $0.33 \mathrm{M}$ sorbitol, $50 \mathrm{mM}$ Hepes, $\mathrm{pH} 8,1 \mathrm{mM} \mathrm{MgCl}$, and $2 \mathrm{mM} \mathrm{Na}_{2}$ EDTA). The mixture was then filtered through two layers of Mira cloth and centrifuged at $10,000 \times g$ at $4{ }^{\circ} \mathrm{C}$ for $15 \mathrm{~min}$. The sediment was resuspended in the same buffer, and the chlorophyll concentration was adjusted to $10 \mu \mathrm{g} /$ $\mathrm{ml} .77 \mathrm{~K}$ fluorescence emission spectra were recorded from 650 to $800 \mathrm{~nm}$ after excitation at $435 \mathrm{~nm}$ using the spectrofluorometer (F-7000, Hitachi, Japan) (Stockel and Oelmuller 
Table 2 Dry matter, yield, and leaf area per plant at silking and maximum leaf area index of five maize hybrids cultivated under different densities in 2017 and 2018

\begin{tabular}{|c|c|c|c|c|c|c|c|}
\hline \multirow[t]{2}{*}{ Year } & \multirow[t]{2}{*}{ Cultivar } & \multirow[t]{2}{*}{ Density } & \multicolumn{2}{|c|}{ Dry matter per plant $\left(\mathrm{g} \cdot\right.$ plant $\left.^{-1}\right)$} & \multirow[t]{2}{*}{ Yield per plant $\left(\mathrm{g} \cdot\right.$ plant $\left.^{-1}\right)$} & \multirow{2}{*}{$\begin{array}{l}\text { Leaf area per plant } \\
\left(10^{3} \mathrm{~cm}^{2} \cdot \text { plant }^{-1}\right)\end{array}$} & \multirow[t]{2}{*}{ LAI } \\
\hline & & & Silking & Maturity & & & \\
\hline \multirow[t]{19}{*}{2017} & \multirow[t]{3}{*}{ SC704 } & $7.5(\mathrm{~L})$ & $176.38 \pm 11.65 \mathrm{a}$ & $421.73 \pm 21.97 b$ & $220.34 \pm 9.25 b$ & $7.08 \pm 0.28 \mathrm{abcd}$ & $5.31 \pm 0.21 \mathrm{gh}$ \\
\hline & & $10.5(\mathrm{M})$ & $161.38 \pm 11.75 \mathrm{ab}$ & $326.06 \pm 23.15 d$ & $173.44 \pm 18.81 \mathrm{~cd}$ & $6.98 \pm 0.41 \mathrm{abcde}$ & $7.33 \pm 0.43 d$ \\
\hline & & $13.5(\mathrm{H})$ & $117.07 \pm 13.19 \mathrm{e}$ & $277.95 \pm 19.47 \mathrm{ef}$ & $99.73 \pm 6.61 \mathrm{f}$ & $5.99 \pm 0.36 \mathrm{fg}$ & $8.09 \pm 0.49 \mathrm{~cd}$ \\
\hline & \multirow[t]{3}{*}{ ZD958 } & $7.5(\mathrm{~L})$ & $136.65 \pm 9.41 \mathrm{~cd}$ & $408.40 \pm 8.99 b$ & $216.60 \pm 21.42 \mathrm{a}$ & $7.23 \pm 0.74 \mathrm{abc}$ & $5.42 \pm 0.56 f g h$ \\
\hline & & $10.5(\mathrm{M})$ & $139.88 \pm 10.57 \mathrm{~cd}$ & $316.00 \pm 12.01 \mathrm{de}$ & $178.34 \pm 6.49 c$ & $7.70 \pm 0.74 a$ & $8.08 \pm 0.78 \mathrm{~cd}$ \\
\hline & & $13.5(\mathrm{H})$ & $119.76 \pm 2.85 \mathrm{e}$ & $255.35 \pm 35.48 \mathrm{f}$ & $139.86 \pm 8.20 \mathrm{ef}$ & $6.78 \pm 0.47 \mathrm{bcdef}$ & $9.15 \pm 0.64 \mathrm{ab}$ \\
\hline & \multirow[t]{3}{*}{ XY335 } & $7.5(\mathrm{~L})$ & $144.86 \pm 10.41 \mathrm{~cd}$ & $501.32 \pm 42.50 \mathrm{a}$ & $256.38 \pm 8.41 \mathrm{a}$ & $6.36 \pm 0.55 \mathrm{cdefg}$ & $4.77 \pm 0.42 \mathrm{hi}$ \\
\hline & & $10.5(\mathrm{M})$ & $140.46 \pm 4.54 \mathrm{~cd}$ & $401.12 \pm 42.33 b c$ & $186.96 \pm 16.04 b$ & $6.19 \pm 0.31 \mathrm{efg}$ & $6.50 \pm 0.33 \mathrm{e}$ \\
\hline & & $13.5(\mathrm{H})$ & $120.49 \pm 7.86 \mathrm{e}$ & $297.73 \pm 29.47 \mathrm{def}$ & $146.74 \pm 11.94 \mathrm{de}$ & $6.94 \pm 0.09$ abcde & $9.37 \pm 0.13 \mathrm{a}$ \\
\hline & \multirow[t]{3}{*}{ LY66 } & $7.5(\mathrm{~L})$ & $174.26 \pm 15.37 \mathrm{a}$ & $499.03 \pm 10.90 \mathrm{a}$ & $265.09 \pm 10.16 \mathrm{a}$ & $7.61 \pm 0.42 \mathrm{ab}$ & $5.71 \pm 0.32 \mathrm{efg}$ \\
\hline & & $10.5(\mathrm{M})$ & $151.84 \pm 9.46 \mathrm{bc}$ & $364.80 \pm 1.35 \mathrm{c}$ & $227.83 \pm 7.68 \mathrm{~b}$ & $7.21 \pm 0.59 \mathrm{abc}$ & $7.57 \pm 0.62 d$ \\
\hline & & $13.5(\mathrm{H})$ & $115.46 \pm 6.86 \mathrm{e}$ & $295.37 \pm 22.56 \mathrm{def}$ & $130.80 \pm 7.12 f$ & $6.31 \pm 0.07 \mathrm{defg}$ & $8.52 \pm 0.10 b c$ \\
\hline & \multirow[t]{3}{*}{ DH618 } & $7.5(\mathrm{~L})$ & $131.45 \pm 5.37 \mathrm{de}$ & $366.75 \pm 26.70 c$ & $253.28 \pm 4.67 b$ & $5.93 \pm 0.27 \mathrm{fg}$ & $4.45 \pm 0.20 \mathrm{i}$ \\
\hline & & $10.5(\mathrm{M})$ & $115.62 \pm 8.79 \mathrm{e}$ & $316.32 \pm 15.94 \mathrm{de}$ & $213.73 \pm 8.84 \mathrm{~cd}$ & $5.89 \pm 0.38 \mathrm{~g}$ & $6.18 \pm 0.40 \mathrm{ef}$ \\
\hline & & $13.5(\mathrm{H})$ & $98.70 \pm 5.56 f$ & $287.24 \pm 6.56 \mathrm{def}$ & $161.63 \pm 0.46 \mathrm{~g}$ & $5.78 \pm 0.24 \mathrm{~g}$ & $7.81 \pm 0.32 \mathrm{~cd}$ \\
\hline & \multicolumn{7}{|l|}{ ANOVA } \\
\hline & Density (D) & & $71.595 * *$ & $177.332 * *$ & $329.78 * *$ & $5.05 *$ & $219.478 * *$ \\
\hline & Variety (V) & & $22.301 * *$ & $21.307 * *$ & $26.423 * *$ & $12.232 * *$ & $12.178^{* *}$ \\
\hline & $\mathrm{D} \times \mathrm{V}$ & & $3.872 * *$ & $4.069 * *$ & $5.088 * *$ & $2.993 *$ & $3.539 * *$ \\
\hline \multirow[t]{12}{*}{2018} & \multirow[t]{2}{*}{ SC704 } & $6.3(\mathrm{~L})$ & $167.07 \pm 18.31 \mathrm{a}$ & $386.50 \pm 15.83 d$ & $249.48 \pm 18.29 a$ & $7.92 \pm 0.97 b$ & $4.95 \pm 0.60 \mathrm{~d}$ \\
\hline & & $11.3(\mathrm{H})$ & $149.24 \pm 21.02 \mathrm{ab}$ & $330.95 \pm 43.35 \mathrm{e}$ & $150.03 \pm 12.60 \mathrm{~d}$ & $7.56 \pm 0.88 b c$ & $8.52 \pm 0.99 a$ \\
\hline & \multirow[t]{2}{*}{ ZD958 } & $6.9(\mathrm{~L})$ & $164.22 \pm 8.55 \mathrm{a}$ & $436.57 \pm 16.71 \mathrm{c}$ & $271.93 \pm 5.60 \mathrm{a}$ & $9.04 \pm 0.51 \mathrm{a}$ & $6.20 \pm 0.35 b c$ \\
\hline & & $9.7(\mathrm{M})$ & $156.87 \pm 15.32 \mathrm{ab}$ & $286.25 \pm 12.43 \mathrm{f}$ & $208.28 \pm 27.44 \mathrm{~b}$ & $8.35 \pm 0.33 \mathrm{ab}$ & $8.14 \pm 0.32 \mathrm{a}$ \\
\hline & \multirow[t]{2}{*}{ XY335 } & $7.0(\mathrm{~L})$ & $144.00 \pm 2.56 \mathrm{ab}$ & $518.62 \pm 41.65 a$ & $259.56 \pm 27.94 a$ & $7.93 \pm 0.30 b$ & $5.53 \pm 0.21 \mathrm{~cd}$ \\
\hline & & $11.1(\mathrm{H})$ & $103.60 \pm 13.50 \mathrm{~d}$ & $420.51 \pm 15.66 \mathrm{~cd}$ & $175.27 \pm 19.95 \mathrm{~cd}$ & $6.27 \pm 0.42 \mathrm{~d}$ & $6.95 \pm 0.47 b$ \\
\hline & \multirow[t]{2}{*}{ DH618 } & $7.5(\mathrm{~L})$ & $134.95 \pm 5.90 \mathrm{bc}$ & $477.15 \pm 25.51 b$ & $256.87 \pm 13.60 \mathrm{a}$ & $6.87 \pm 0.08 \mathrm{~cd}$ & $5.17 \pm 0.06 \mathrm{~d}$ \\
\hline & & $9.9(\mathrm{M})$ & $118.70 \pm 11.06 \mathrm{~cd}$ & $345.20 \pm 18.39 \mathrm{e}$ & $203.06 \pm 10.52 b c$ & $6.87 \pm 0.34 \mathrm{~cd}$ & $6.77 \pm 0.33 b$ \\
\hline & \multicolumn{7}{|l|}{ ANOVA } \\
\hline & Density (D) & & $4.245 \mathrm{~ns}$ & $141.952 * *$ & $125.2 * *$ & $3.491 \mathrm{~ns}$ & $123.743 * *$ \\
\hline & Variety (V) & & $11.282 * *$ & $32.493 * *$ & $6.676^{* *}$ & $12.252 * *$ & $6.802 * *$ \\
\hline & $\mathrm{D} \times \mathrm{V}$ & & $3.894 *$ & $5.188 *$ & $2.322 \mathrm{~ns}$ & $4.344 *$ & $10.994 * *$ \\
\hline
\end{tabular}

The mean values indicated within a column and the same site followed by different letters are significant differences at $p<0.05$. L denotes plant density $\leq 7.5$ plants $\mathrm{m}^{-2}$. M denotes plant density $>7.5$ and $\leq 10.5$ plants $\mathrm{m}^{-2}$. H denotes plant density $>10.5$ plants $\mathrm{m}^{-2}$

2004). A total of three biological replicates were performed for each treatment.

\section{Stomata analysis}

Stomatal density and the stomatal aperture area were measured at the filling stage using nail polish impressions (Zheng et al. 2013). Specifically, colorless nail polish was evenly applied to the abaxial surface of the ear leaf in order to obtain a replica of the leaf surface. The impressions were then observed under a microscope (DM5500B, Leica Corp, Biberach, Germany) equipped with a digital camera (DFC300-FX, Leica Corp). The stomatal density was determined by counting the number of stomata in 18 fields of view per treatment. To determine the stomatal aperture area, nine stomata were randomly selected from different images captured under the microscope for each sample, four replications were performed for each treatment (totaling 36 stomata per treatment), and the stomatal aperture area was measured using ImageJ (NIH, Bethesda, MD, USA).

\section{The ratio of red to far-red light}

The ratio of red to far-red light was measured using a handheld spectrometer (HR-350, HiPoint Co., Ltd., Taiwan) at the ear and ground positions around noon at the silking and 
filling stages on a sunny, cloudless day. The device was kept vertically to the soil surface with the sensor backing against the plant and facing north, east, south, and west. The average of the four estimated values was used for analysis (Zhu et al. 2014). R/FR was calculated as the ratio of spectral irradiance measured in the bands at 655 to $665 \mathrm{~nm}$ (red) over the irradiance measured in the bands 725 to $735 \mathrm{~nm}$ (far red). A total of three independent replicates were performed for each treatment.

\section{Statistical analysis}

Data were prepared and calculations were performed using Microsoft Excel 2016. An analysis of variance was performed with SPSS 21.0 (SPSS Institute Inc., US) in order to test for differences between treatments. The significance level was set at the 0.05 probability level. The statistical analysis for each year and growth stages was performed separately. The figures were generated using Origin Pro 8.0.

\section{Results}

\section{Grain yield and yield components}

The effects of density and variety on grain yield were all significant during the two growing seasons, whereas the density $\times$ variety interaction only had a significant effect on grain yield in the year 2017. The grain yield of five maize cultivars at medium planting density $\left(105,000\right.$ plants $\left.\mathrm{ha}^{-1}\right)$ was greater than that observed at low density $(75,000$ plants $\mathrm{ha}^{-1}$ ) by $2.09-20.32 \%$ in both years (Table 1 ). Interestingly, increasing planting density from medium to high $(105,000$ to 135,000 plants ha ${ }^{-1}$ ) did not significantly change the grain yield of DH618, ZD985, and XY335, but caused a remarkable decrease in SC704 and LY66 (26.08\% and 26.18\%, respectively, compared to grain yield at medium density). Notably, the grain yield of SC704 and LY66 cultivated at high density was even lower than their yield under low density condition (Table 1). Comparing the five varieties, the highest grain yield was observed in LY66 at medium density, followed by DH618 in 2017.

Ear number increased with higher planting densities by $12.9-62.1 \%$ in all five maize cultivars in both years. In contrast, the kernel number per ear and the 1000-kernel weight (TKW) decreased with higher planting densities in both years. Importantly, both density and variety had significant impacts on kernel number per ear and the 1000-kernel weight, and the interaction between these factors had a dramatic effect on kernel number per ear while only marginally influencing the 1000-kernel weight in both years. LY66 and DH618 had relatively higher TKW than other cultivars, suggesting that TKW influences grain yield performance in response to changes in planting density. Additionally, the earless plant rate of SC704 cultivated at high density was up to $32.8 \%$ in 2017.

Increasing plant density significantly decreased the yield per plant, especially under high-density conditions (Table 2). Compared to other cultivars, LY66 and DH618 showed relatively higher yields per plant under the medium density cultivation condition. This is consistent with observations of the grain yield per plot and indicates different maize cultivars have different density tolerance. Overall, the increased yield per plant under medium and high-density conditions is important for further increasing the plant yield per area.

\section{Dry matter accumulation}

Dry matter accumulation and distribution directly influence crop yield. Accordingly, we observed a significant influence of density, variety, and their interaction (density $\times$ variety), in the plant biomass measured at the silking and maturity stages. At the level of individual plants, the biomass at the silking and maturity stages declined as planting density increased in both years (Table 2). The dry matter per plant of DH618 cultivated at high density was lower compared to low density conditions by $21.68 \%$. Similarly, we observed a proportional decrease of $34.09-40.81 \%$ for the ZD958, XY335, LY66, and SC704 varieties. This difference can help explaining the overall higher yield per plant obtained for DH618.

At the maize population level, total biomass accumulation increased as a function of planting density (Table 1). This tendency is consistent with the results obtained for yield, but is not exactly the same. For example, XY335 showed the highest total biomass at medium density conditions, but its overall yield was lower than both DH618 and LY66 (Table 1). Considering that only the biomass located to the seed contributes to yield, we further measured the harvest index (HI) across all varieties and density treatments. XY335 had the lowest HI of all maize cultivars. In contrast, DH618 and LY66 had the highest HI which, along with the observed higher total biomass accumulation in the latter two, suggests that biomass accumulation and its efficient distribution to seeds determines maize yield.

\section{Leaf area and leaf area index}

According to previous studies, the leaf area and the leaf area index (LAI) are important parameters determining photosynthetic capacity (Sinclair et al. 2004), whereby we measured both of these parameters in order to understand the relationship between photosynthesis and maize yield. Our results demonstrated that LAI was significantly influenced by planting density and cultivar variety in both years. Specifically, the LAI at the silking stage increased 
significantly in all maize cultivars with increasing planting density (Table 2). In contrast, the leaf area per plant at the silking stage decreased as planting density increased (Table 2). Interestingly, no significant changes in leaf area were observed in ZD958 and XY335 (in 2017), and DH618 (in 2017 and 2018), between different planting densities. The leaf area per plant of the LY66 and SC704 cultivars grown at high density significantly decreased by $17.11 \%$ and $15.36 \%$ when compared to plants grown at low density in 2017. Moreover, the leaf area per plant and the LAI of DH618 were lower than in other cultivars, respectively, averaging 5.86 and 6.15 (Table 2). These results suggested that higher leaf area per plant and leaf area index do not necessarily improve maize yield.

\section{Gas exchange and dark respiration}

Photosynthetic assimilation during post-silking is a critical determinant of grain yield. In order to better understand the changes in photosynthesis at different developmental stages, we measured the photosynthetic rate $\left(\mathrm{P}_{\mathrm{n}}\right)$ of ear leaves at the silking, filling and maturity stages in the field. Our measurements showed that $\mathrm{P}_{\mathrm{n}}$ and $T_{\mathrm{r}}$ decreased significantly at the maturity stage in all maize cultivars in both 2017 and 2018 . When compared to other cultivars, DH618 and LY66 had higher $P_{n}$ and $T_{r}$ at the maturity stage, which means that the former slowly declined in both cultivars during the filling stage, maintaining a relatively high photosynthetic activity at the maturity stage (Figs. 2, 3). During the early reproductive stage, no significant differences in $P_{n}$ were observed between
Fig. 2 Photosynthetic characteristics of the ear leaf at the silking, filling, and maturity stages, as influenced by plant density in 2017. Different lowercase letters indicate significant differences $(p<0.05)$ between treatments. $\mathrm{P}_{\mathrm{n}}$, net photosynthetic rate; $\mathrm{G}_{\mathrm{s}}$, stomatal conductance; $\mathrm{C}_{\mathrm{i}}$, intercellular $\mathrm{CO}_{2}$ concentration; $\mathrm{T}_{\mathrm{r}}$, transpiration rate. SL, SC704 at low density; SM, SC704 at medium density; SH, SC704 at high density; ZL, ZD958 at low density; ZM, ZD958 at medium density; ZH, ZD958 at high density; XL, XY335 at low density; XM, XY335 at medium density; $\mathrm{XH}, \mathrm{XY} 335$ at high density; LL, LY66 at low density; LM, LY66 at medium density; LH, LY66 at high density; DL, DH618 at low density; DM, DH618 at medium density; DH, DH618 at high density

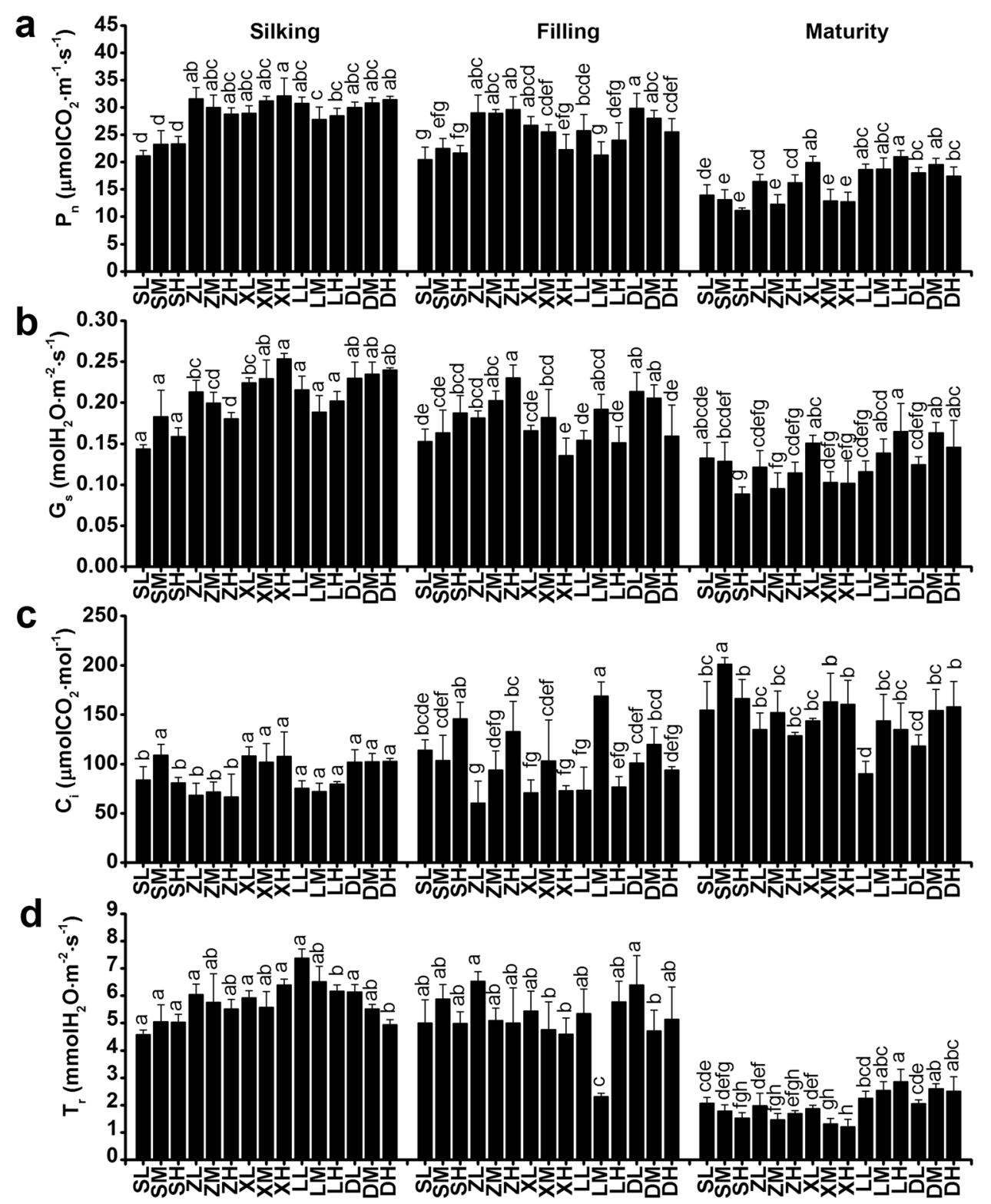


Fig. 3 Photosynthetic characteristics of the ear leaf at the silking, filling, and maturity stages, as influenced by plant density in 2018. Different lowercase letters indicate significant differences $(p<0.05)$ between treatments. $\mathrm{P}_{\mathrm{n}}$, net photosynthetic rate; $\mathrm{G}_{\mathrm{s}}$, stomatal conductance; $\mathrm{C}_{\mathrm{i}}$, intercellular $\mathrm{CO}_{2}$ concentration; $\mathrm{T}_{\mathrm{r}}$, transpiration rate. SL, SC704 at low density; SM, SC704 at medium density; SH, SC704 at high density; ZL, ZD958 at low density; ZM, ZD958 at medium density; ZH, ZD958 at high density; XL, XY335 at low density; XM, XY335 at medium density; XH, XY335 at high density; LL, LY66 at low density; LM, LY66 at medium density; LH, LY66 at high density; DL, DH618 at low density; DM, DH618 at medium density; DH, DH618 at high density

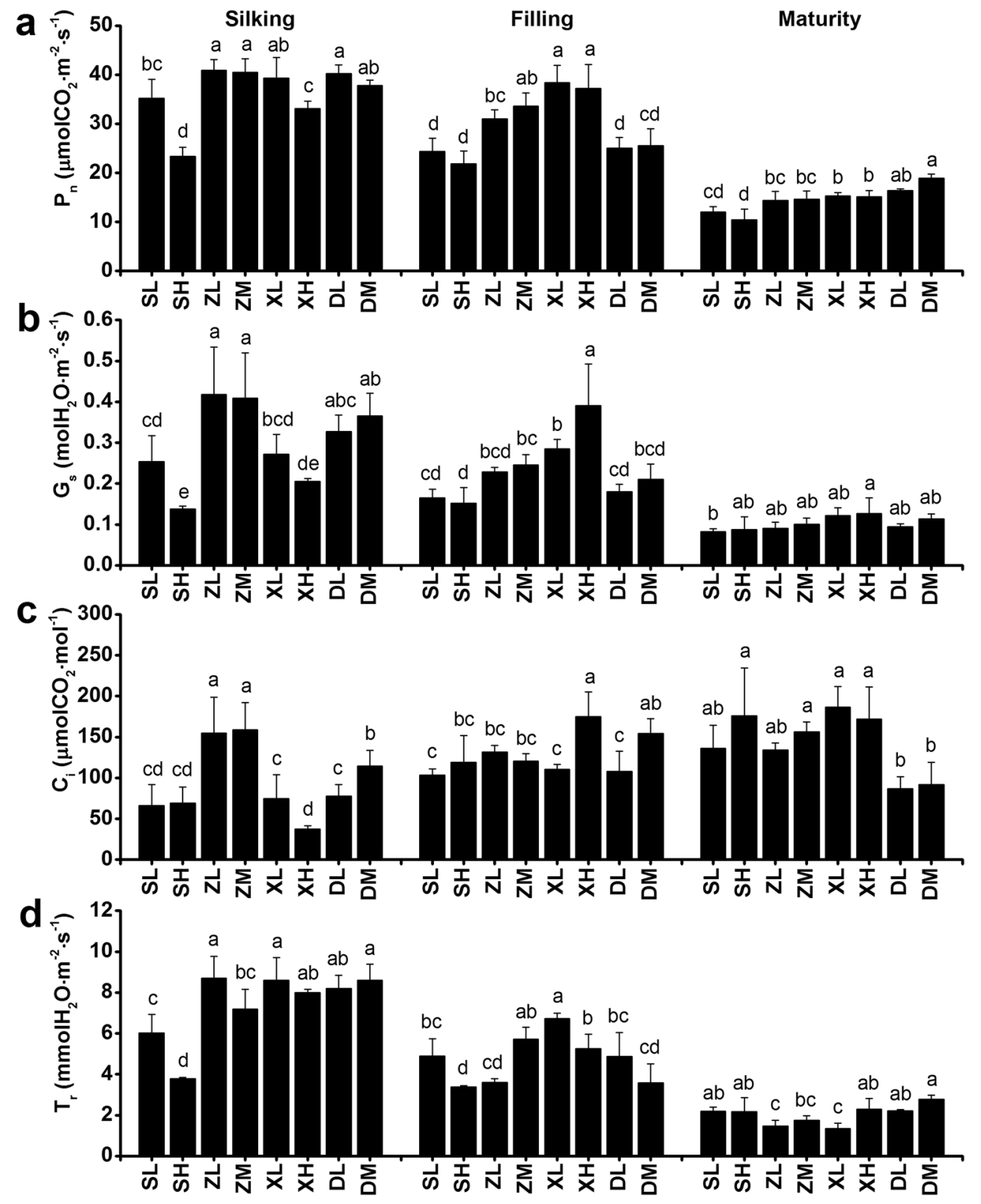

four of the maize cultivars at the silking stage, which averaged 29.00-30.73 $\mu \mathrm{molCO}_{2} \mathrm{~m}^{-2} \mathrm{~s}^{-1}$. During the silking and filling stages, the SC704 cultivar showed a $22.20-26.60 \%$ lower $\mathrm{P}_{\mathrm{n}}$ compared to the remaining varieties. In 2017, the planting density did not significantly impact the $P_{n}$ of the ear leaves during all three growing stages (Fig. 2a). However, in 2018, the increase in planting density led to a significant decrease in the $\mathrm{P}_{\mathrm{n}}$ of SC704 and XY335 at the silking stage, despite no significant differences existed at the filling and maturity stages (Fig. 3a).

Additionally, $G_{s}, C_{i}$, and $T_{r}$ followed a similar trend to $P_{n}$ for the different planting density treatments while causing a significant reduction in the $R_{\mathrm{d}}$ at night during the silking stage in both 2017 and 2018 (Fig. 4). At the filling and maturity stages, no significant differences were detected in the $R_{\mathrm{d}}$ across four cultivars (Fig. $4 \mathrm{~b}$ ). Finally, we also analyzed the stomatal status but found no changes on stomatal density and aperture area between treatments at the filling stage (Fig. S1).

\section{Pigment content}

Since we detected small differences in gas exchange and respiration rate between different planting densities, we opted to further analyze the amount and composition of pigments. Overall, the amount of chlorophyll $a$, chlorophyll $b$, and carotenoids decreased with increasing planting density during the growing season (Fig. 5a-c), and 
Fig. 4 Dark respiration rate of maize ear leaves in 2017 (a) and 2018 (b). Different lowercase letters indicate significant differences $(p<0.05)$ between treatments. $R_{d}$, dark respiration rate

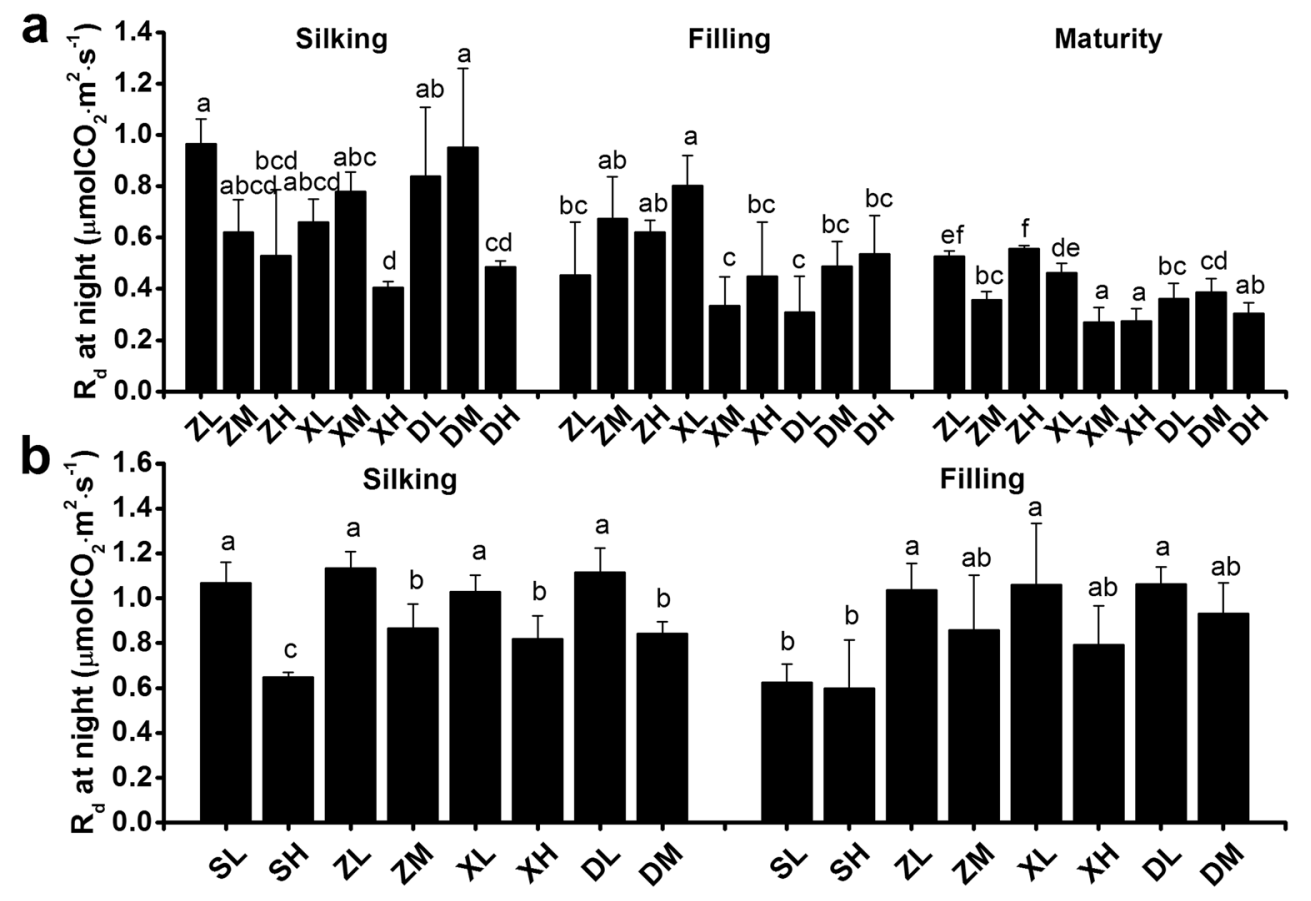

decreased in the following order for different cultivars: DH618 > XY335 > ZD958. The latter trend is similar to the observed grain yield in the year 2017 (Fig. 5, Fig. S2). The amount of chlorophyll $a$ did not significantly change from the silking to the maturity stage, while the amount of chlorophyll $b$ decreased after the silking stage and then increased at physiological maturity, resulting in a significant increase in the chlorophyll $a / b$ ratio at the filling stage (Fig. $5 \mathrm{~d}$ ).

\section{$77 \mathrm{~K}$ chlorophyll fluorescence}

To further examine the underlying reason behind differences in photosynthesis, we performed a fluorescence emission analysis at $77 \mathrm{~K}$. All treatments showed similar $77 \mathrm{~K}$ fluorescence spectra, with emission peaks at $685 \mathrm{~nm}$ and $735 \mathrm{~nm}$ (Fig. 6a-c). The emission signal at $685 \mathrm{~nm}$ did not significantly differ between planting density treatments (Fig. 6d), nor did the F735/F685 ratio, an indicator of the excitation energy distribution between photosystems II and I (Fig. 6f). These data might explain the insensitivity of the photosynthetic rate in the ear leaves in response to increased planting density (Fig. 6, Fig. S3).

\section{The ratio of red to far-red light}

Light quality changes as planting densities increase in a canopy. The light that passes through a canopy of leaves has a reduced red to far-red ratio (Holalu and Finlayson 2017). The ability of plants to adjust their morphology and physiology in response to light quality changes in natural environments might play an important role in plant development and grain yield. As shown in Fig. S4, the R/FR significantly decreased with increasing planting density on leaves located in the ear position at the silking stage in 2017 (except for DH618), and the filling stage in 2018. Additionally, the R/ FR ratio on leaves located in ground positions decreased to a significant level in SC704 and XY335 under high-density conditions. However, the R/FR ratio of ZD958, LY66 and DH618 were not seemingly affected by different density treatments in leaves located in the ground position (Fig. $\mathrm{S} 4 \mathrm{a}, \mathrm{c})$. A similar trend was observed in the ear position at the filling stage in 2017, and the silking stage in 2018. In general, the R/FR ratio of DH618 was not significantly affected by increasing planting density, indicating that a better shoot structure can minimize the competition for light and the effects caused by increased shading.

\section{Relationships of maize grain yield and photosynthetic capacity confirmed by genotypes released in different years}

As shown in Fig. 7, a correlation analysis between different traits and the years of hybrid release showed that yield is positively correlated with the year of hybrid release $\left(R^{2}=0.49\right.$, $p<0.01$ ), suggesting the possibility of cultivar improvement over the years. In contrast, the ratio of chlorophyll $\mathrm{a} / \mathrm{b}$ at the silking $(\mathrm{A} / \mathrm{BS})$ and filling $(\mathrm{A} / \mathrm{BF})$ stages is negatively correlated with hybrid release year $\left(R^{2}=0.71, p<0.01\right.$ and $\left.R^{2}=0.29, p<0.05\right)$. We further integrated data from other publications with our experimental data to confirm the relationship between $\mathrm{P}_{\mathrm{n}}$ and hybrid release year. Our results clearly 
Fig. 5 Pigment content and chlorophyll $a / b$ ratio of the ear leaf during the growing season in 2017. a Amount of chlorophyll $a$; b Amount of chlorophyll $b$; c Amount of carotenoids; $\mathbf{d}$ chlorophyll $a / b$ ratio. Different lowercase letters at the same growth stage indicate significant differences $(p<0.05)$ between treatments

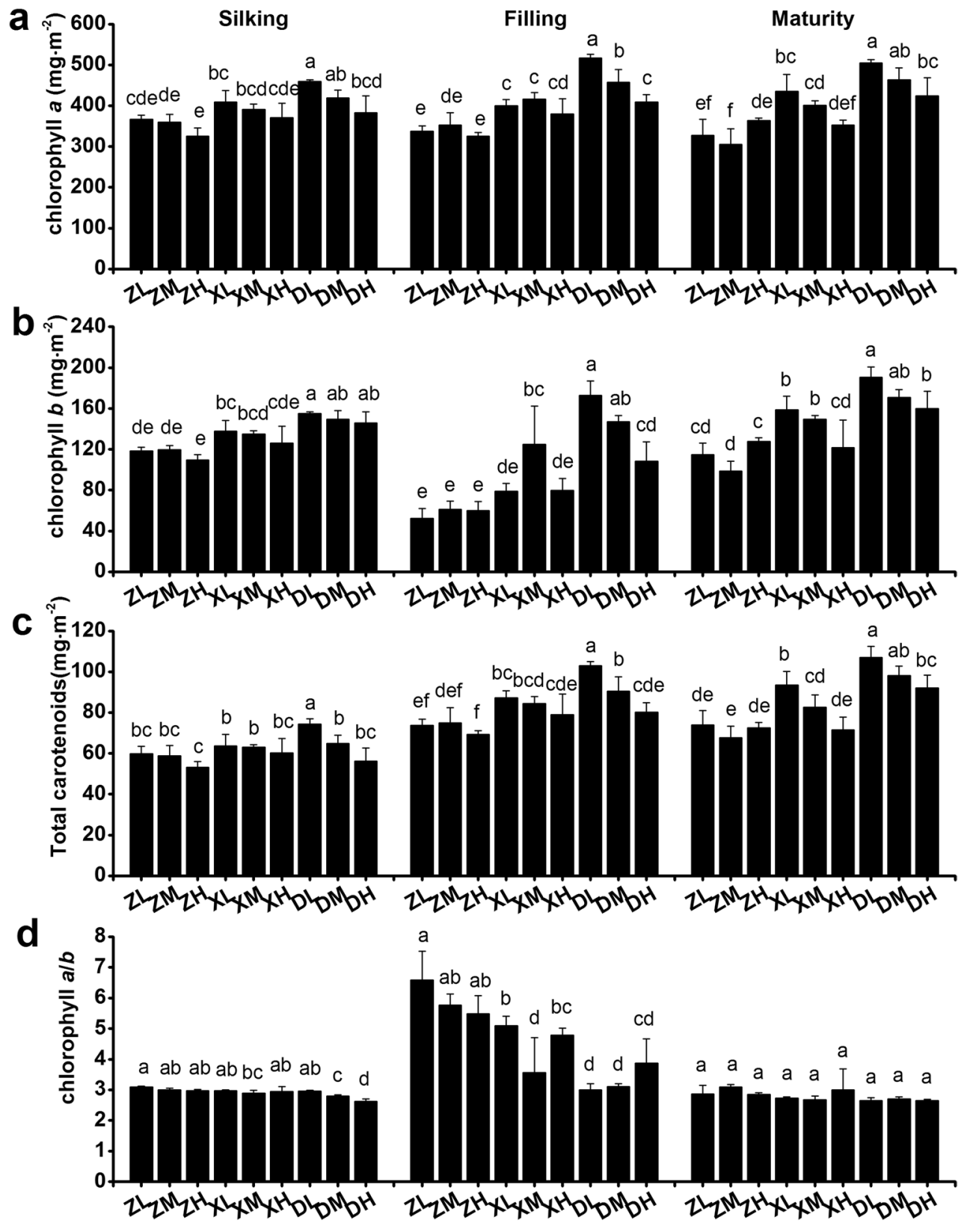

showed an increasing trend in the $\mathrm{P}_{\mathrm{n}}$ from the 1970s to $2010 \mathrm{~s}$ $\left(R^{2}=0.58, p<0.01\right)$.

\section{Correlation analysis}

Figure 8 shows the results of a correlation analysis between all physiological parameters measured over the 2 years of field experiments. In both 2017 and 2018, the R/FR ratio at the filling stage has a significantly positive correlation with yield per plant (YP) and the 1000-kernel weight (TKW), which was stronger for the former. Additionally, the TKW has a positive correlation with grain yield (Y) and YP, while the dry matter per plant at the silking stage (DMPS) and the dry matter per plant at the maturity stage (DMPM) were both significantly correlated with YP in 2017, Moreover, DMPM showed a strong positive correlation with YP in 2018. Our analyses also showed that the maximum LAI (MLAI) was negatively correlated with YP but uncorrelated with $\mathrm{Y}$. The $\mathrm{P}_{\mathrm{n}}$ at maturity $\left(\mathrm{P}_{\mathrm{n}} \mathrm{M}\right)$ was positively correlated with $\mathrm{Y}$ and TKW, but only significantly with the latter in 2017. Interestingly, significantly negative correlations were discovered between chlorophyll $a / b$ and grain yield in both 2017 and 2018. 


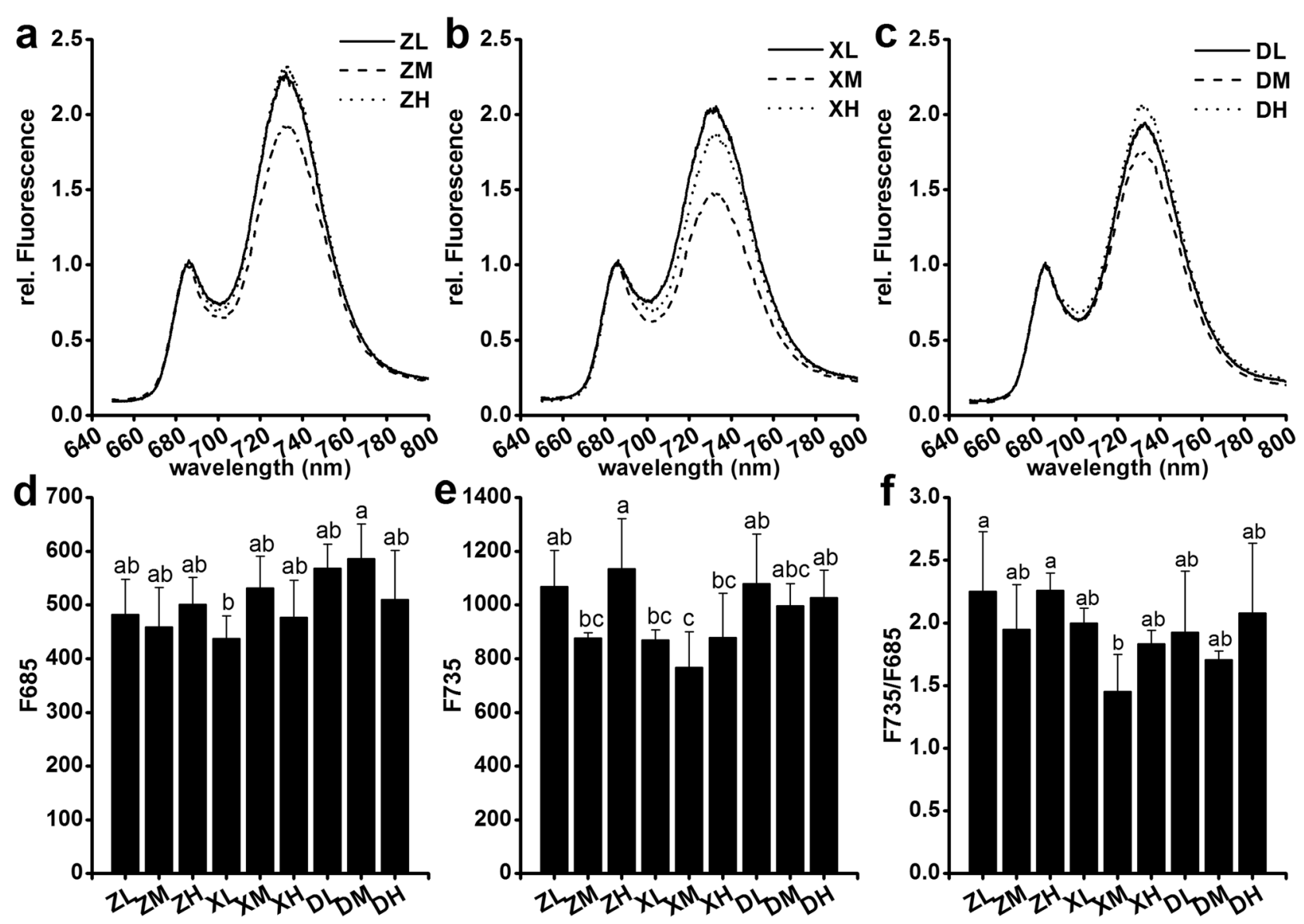

Fig. 6 77K fluorescence emission spectra of the ear leaf at the filling stage in 2017. a-c $77 \mathrm{~K}$ fluorescence emission spectra after excitation at $435 \mathrm{~nm}$. The chlorophyll concentration was adjusted to $10 \mu \mathrm{g} / \mathrm{ml}$. The values were normalized to the emission at $685 \mathrm{~nm}$. d-f $77 \mathrm{~K} \mathrm{flu}-$ orescence emission at $685 \mathrm{~nm}$ and $735 \mathrm{~nm}$ and the F735/F685 ratio. Different lowercase letters at the same growth stage indicate significant differences $(p<0.05)$ between treatments

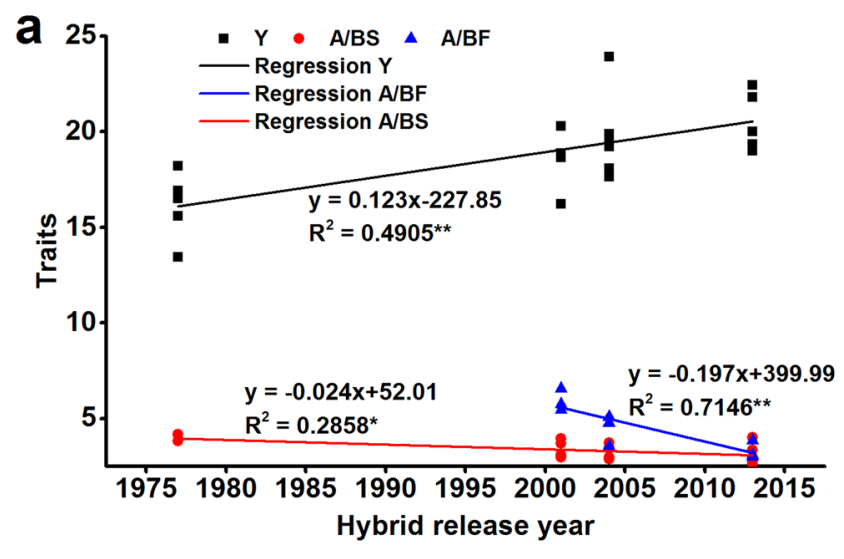

Fig. 7 Trends in grain yield, net photosynthesis, and chlorophyll $a / b$ ratio at the silking and filling stages over the hybrid release year. $\mathrm{Y}$, grain yield; $\mathrm{PnS}, \mathrm{P}_{\mathrm{n}}$ at silking stage; $\mathrm{PnM}, \mathrm{P}_{\mathrm{n}}$ at maturity; $\mathrm{A} / \mathrm{BS}$, chlorophyll $a / b$ at silking stage; $\mathrm{A} / \mathrm{BF}$, chlorophyll $a / b$ ratio at filling

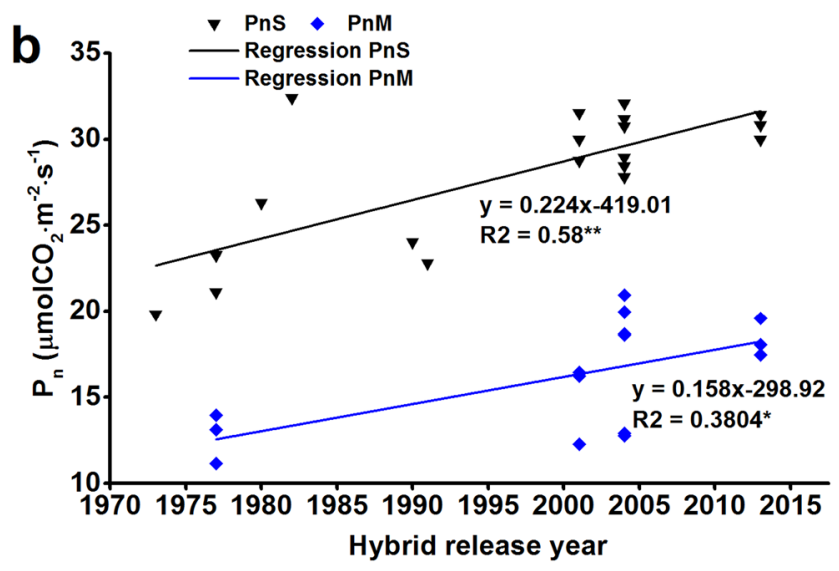

stage. Data from previous studies, including maize varieties released between the 1970-1990 decades, were integrated into this figure (Zhang et al. 1992; Ding et al. 2006; Zhang et al. 2011; Li et al. 2015) 


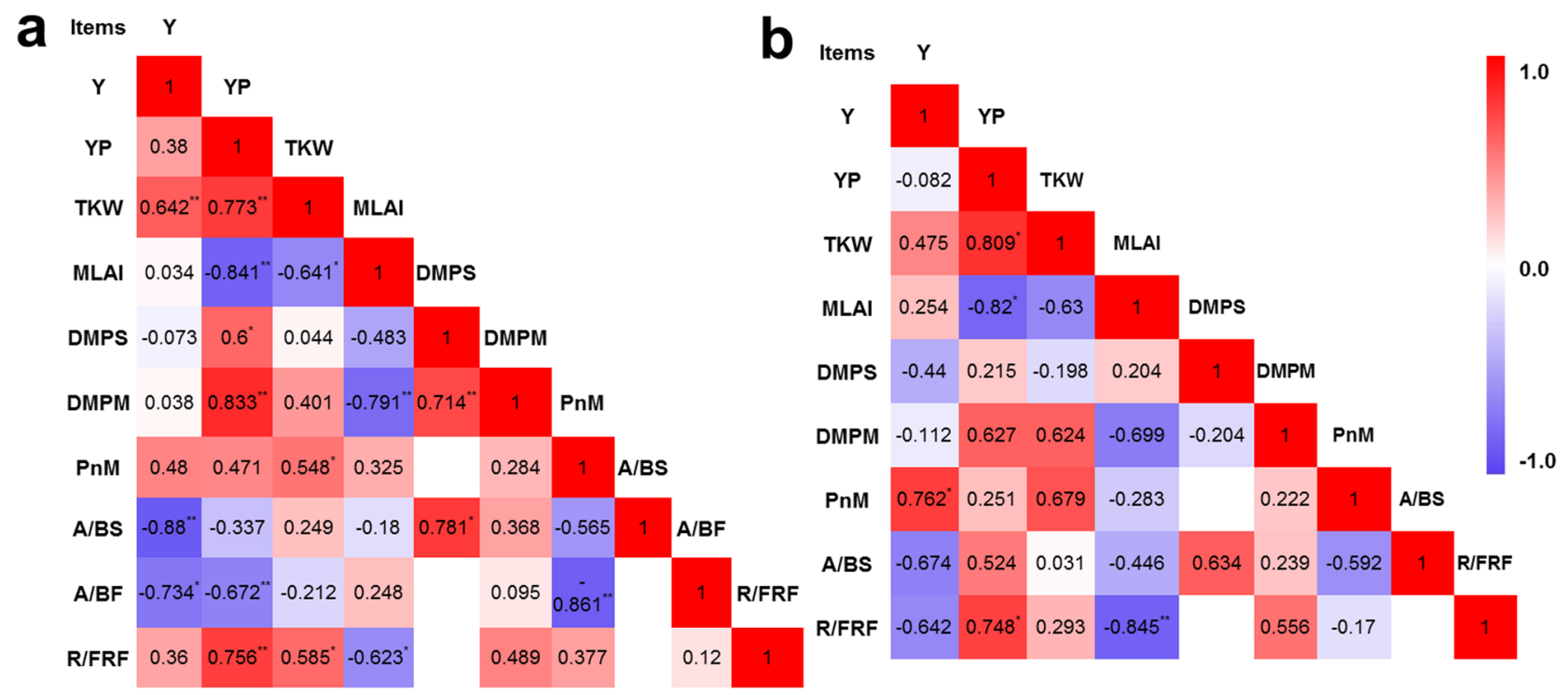

Fig. 8 Relationship between grain yield and main physiological indices during the growing stage in 2017 (a) and 2018 (b). Y, grain yield; YP, yield per plant; TKW, 1000-kernel weight; MLAI, maximum LAI; DMPS, dry matter per plant at silking stage; DMPM, dry

\section{Discussion}

\section{Increase of maize yield potential by cultivar improvement}

China's population is expected to peak in 2033. Accordingly, grain production needs to increase by at least $35 \%$ over the next two decades to meet the demand of the rising population (Zhang 2011). Maize grain yield has continuously increased in the past decades due to advances in farming technology and maize hybrids. Increasing plant density is one important management practice for improving maize yield (van Ittersum and Cassman 2013; Zhang et al. 2020; Sher et al. 2017). However, there is a curvilinear response between grain yield per area and plant density in modern maize hybrids, demonstrating that yield will not increase indefinitely as plant density exceeds the optimal level (Mastrodomenico et al. 2018; Wei et al. 2019). In this study, we used five maize hybrid cultivars to analyze the physiological mechanisms that are potentially responsible for further increasing yield potential. We found the replacement of maize cultivars leading to enhanced tolerance to high planting density, higher yield per plant and higher grain yield per area (Table 1, Table 2 and Table S1).

The grain yield of the oldest cultivar, SC704, drastically decreased at high cultivation densities $(135,000$ plants $\mathrm{ha}^{-1}$ ), largely owing to a sharp decrease in HI that was associated with an increase in barren plants (earless plant rate up to $32.8 \%$ ). The second oldest cultivar, ZD958, has matter per plant at maturity; $\mathrm{PnM}, \mathrm{P}_{\mathrm{n}}$ at maturity; $\mathrm{A} / \mathrm{BS}$, chlorophyll $a / b$ ratio at silking stage; $\mathrm{A} / \mathrm{BF}$, chlorophyll $a / b$ ratio at filling stage; R/FRF, R/FR at filling stage. *, ** Significance at the 0.05 and 0.01 probability level, respectively

a higher tolerance to high density its kernel number per ear and TKW are lower than more recent cultivars, which limits yield improvement. The cultivars XY335 and LY66 were both released in 2004, and the grain yield of the latter is the highest under medium planting density, but rapidly decreased at higher densities due to a decrease in the 1000-Kernel weight (16.74\% decrease comparing to low density). Importantly, this indicates that density tolerance constitutes a bottleneck for the yield improvement of this cultivar. Unlike LY66, XY335 has good density tolerance and the highest biomass accumulation among all cultivars analyzed. However, its HI drastically decreased under both medium and high-density conditions. It was reported that modern commercial hybrids generally have enhanced tolerance to increased planting density compared to older maize hybrids (Echarte et al. 2000; Bernhard and Below 2020). DH618 is the newest cultivar of all analyzed and showed a stable high grain yield, the highest TKW and the least decrease in biomass per plant under the high-density condition (Tables 1, 2, Fig. 7 and Table S1). DH618 has higher grain yield resulting from higher 1000-kernel weight, which is related to the source-sink ratio established during the early grain filling stage (Brenda et al. 2006). Overall, our comprehensive comparison of yield components, biomass accumulation and distribution (HI) among five cultivars under three planting density conditions showed important indicators for improving yield potential of modern maize hybrids. 


\section{High-yield cultivars have moderate leaf area with higher photosynthetic capacity and longer photosynthesis duration}

To analyze the relationship between photosynthesis and grain yield, we systematically measured photosynthesisrelated parameters in a time-course manner using five maize cultivars. According to previous research, the high-yield potential depends on appropriate canopy structure, including a favorable LAI that enables source supply (Boomsma et al. 2009; Wei et al. 2017). In this study, an expected increase in LAI was detected with increasing planting densities that facilitates an impressive capturing of solar radiation and leads to a concomitant increase in biomass (Table 1). However, intraspecific competition becomes stronger and light quality in the canopy changes with increased planting density (Yamazaki 2010). In present study, the R/FR ratio showed a close linear relationship with YP and a negative correlation with MLAI (Fig. 8). These observations support the finding that the lower LAI and decreased leaf area per plant in DH618 may be attributed to less mutual shading. Hence, the higher leaf area per plant and the leaf area index do not necessarily improve maize yield, and instead depend on other factors and circumstances. In this case, a moderate LAI could instead be more favorable for photosynthesis and yield formation.

The contribution of photosynthesis to grain yield improvement has been thoroughly debate for some years. Some reports suggested that an enhanced leaf photosynthetic capacity provides a basic avenue for improving maize yield (Long et al. 2015; Ren et al. 2016), while others argued for little correlation between increased photosynthesis and crop yields (Driever et al. 2014; Wu et al. 2018). Our results integrate previously reported data and showed that the photosynthetic rate increased synergistically with the replacement of older maize cultivars with modern varieties (from the 1970s to 2010s) (Figs. 2, 3 and 7), particularly when considering the $\mathrm{P}_{\mathrm{n}}$ at late reproductivity stages. At the same time, we found a positive correlation between $\mathrm{P}_{\mathrm{n}} \mathrm{M}$ and TKW and Y (Fig. 8), in agreement with previous work (Gai et al. 2017). The increased availability of carbohydrates is associated with an increase in the rate of dark respiration under elevated $\mathrm{CO}_{2}$ conditions ( $\mathrm{Li}$ et al. 2013). We found that the $R_{\mathrm{d}}$ of SC704 during the night at the filling stage was lower than other cultivars (Fig. 4), which is consistent with a decrease in the $\mathrm{P}_{\mathrm{n}}$. Moreover, increased dark respiration is associated with higher growth rates, as dark respiration provides ATP and converts carbohydrates to carbon (C) atoms that are needed for growth. Therefore, photosynthesis and respiration are highly coordinated to sustain plant growth. These observations showed that an improved photosynthetic efficiency might be the crucial contributor to higher grain yields.
It has been previously shown that high planting density reduced leaf stomatal density and net photosynthesis, leading to a decreased dry mass accumulation after silking (Yan et al. 2017; Wei et al. 2020). Here, we showed that the incremental increases in planting density do not result in significant differences in net photosynthesis $\left(\mathrm{P}_{\mathrm{n}}\right)$, stomatal conductance $\left(\mathrm{G}_{\mathrm{s}}\right)$, intercellular $\mathrm{CO}_{2}$ concentration $\left(\mathrm{C}_{\mathrm{i}}\right)$, and transpiration rate $\left(\mathrm{T}_{\mathrm{r}}\right)$ of the ear leaves. These results are not necessarily surprising, since changes on leaf traits depend on the plant species under consideration and the experimental treatment conditions. The literature shows that the $P_{n}, G_{s}, T_{r}$, $\mathrm{L}_{\mathrm{s}}$ and LAI first increase and then decreased with growing planting density in wheat (Fang et al. 2018). Here, we collected data at the beginning of the anthesis stage, which is the early reproductive stage, and also found that the $P_{n}, G_{s}$, and $\mathrm{T}_{\mathrm{r}}$ decrease under high-density cultivation conditions (SC704 in 2018), but only at the silking stage. The negative effects of high-density cultivation on $\mathrm{P}_{\mathrm{n}}$ disappeared at the filling and maturity stages in all tested maize cultivars in both 2017 and 2018. Hence, our time-course analysis includes more cultivars and provides a deeper, comprehensive view to changes in the $\mathrm{P}_{\mathrm{n}}$ as a response to planting density. A study in cattails showed that the leaves from low planting density populations had higher stomatal density and index, a thicker mesophyll and a higher proportion of aerenchymal area, even though the evaluated plant developmental stage remains unknown (Corrêa et al. 2017). A further study showed that, compared to low density conditions, high-density cultivation decreased stomatal aperture area by $31.9 \%$ in maize, and that stomatal density was independent of the cultivar and the planting density at the filling stage (Niu et al. 2020). This is partly consistent with our results. In our case, however, neither stomatal density nor stomatal aperture area changed with density treatment at the filling stage. There are two possible reasons for these discrepancies. Firstly, we used a narrow-wide row planting pattern that provides more space and increases the amount of light reaching the ear leaf position. Secondly, the typical physiological responses (i.e., stomata, chlorophyll fluorescence and photosynthesis) to planting density are the result of plant competition for light resources (Wei et al. 2020; Postma et al. 2021). However, Xinjiang has adequate radiation during the growth period of maize, which is likely to reduce the amount of competition for light between different plants. The planting densities $\left(75,000\right.$ plants $\mathrm{ha}^{-1}, 105,000$ plants $\mathrm{ha}^{-1}$ and 135,000 plants ha ${ }^{-1}$ ) did not significantly decrease the fluorescence of chlorophyll $77 \mathrm{~K}$ nor the amount of chlorophyll $a$ and $b$, which is consistent with an unchanged stomatal status. Consequently, the planting densities used in our experiments did not have a significant effect on stomata controlling the supply of $\mathrm{CO}_{2}$ for photosynthesis (Fig. S1), the amount of pigments present nor the fluorescence associated with the photosynthetic processes (Figs. 5, 6, Fig. 
S3). Hence, it did not affect photosynthesis. Surprisingly, we found that DH618 and LY66 maintain a higher $P_{n}$ at maturity at densities of 105,000 and 135,000 plants ha ${ }^{-1}$ (Figs. 2a and $3 a)$. The amount of chlorophyll $b$ in DH618 was higher than other cultivars, and it has been suggested that plants with higher chlorophyll $b$ have slower leaf senescence (Janečková et al. 2019). It is thus possible that DH618 and LY66 may have slower leaf senescence during the reproductive period, consequently resulting in a higher 1000-kernel weight and grain yield (Kusaba et al. 2013).

\section{Physiological indicators for high-yield maize cultivars}

Chloroplasts are the main photosynthetic organelle, and the amount of chlorophyll and composition support the biochemical energy production for the Calvin-Benson cycle by harvesting photons and transporting electrons, which is crucial to determine photosynthesis that accounts for more than $98 \%$ of the variation in maize primary production (Alton 2017; Luo et al. 2019; Gitelson et al. 2008). Previous studies provided compelling evidence that the total amount of chlorophyll is significantly correlated with yield-determining traits, including grain yield (Ghimire et al. 2015). In our study, DH618 had a higher chlorophyll amount than ZD958 and XY335, as well as a lower chlorophyll $a / b$ ratio than the two other cultivars, particularly at the filling stage. As chlorophyll $a$ helps converting energy of absorbed photons to chemical energy, and chlorophyll $b$ is in charge of harvesting light (Björn et al. 2009; Kume et al. 2018), our results suggest that the light-harvesting antennae proteins are much more abundant than the photosystem core proteins in DH618, when compared to other cultivars. The higher amounts of light harvested in DH618 leaves produce higher photosynthetic efficiency and greater amounts of carbohydrates, leading to a higher yield. Notably, the chlorophyll $a / b$ ratio at the silking $\left(R^{2}=0.77^{* *}\right)$ and filling stages $\left(R^{2}=0.54^{*}\right)$ had significantly negative correlations with yield in 2017 (Fig. 8a), and a strong negative association was also observed in 2018 (Fig. 8b). Moreover, the chlorophyll $a / b$ ratio showed a negative correlation with hybrid release year (Fig. 7), whereby we assume that a lower chlorophyll $a / b$ ratio could be used as a new indicator for selecting highyielding cultivars.

\section{Conclusions}

We showed that the difference in maize yield potential in our study is associated with differences in the photosynthetic capacity of different maize cultivars. The cultivars with higher yields and tolerance to planting density exhibited a higher photosynthetic capacity, a longer duration of photosynthesis, a higher amount of chlorophyll with a lower chlorophyll $a / b$ ratio, a moderate leaf area, and LAI. Additionally, maize photosynthesis, dark respiration, stomatal density, and aperture showed no significant changes with increasing planting density. Therefore, we propose that photosynthesis capacity is a primary determinant of maize yield and that both of these factors are not necessarily associated with other physical and physiological traits.

Supplementary Information The online version contains supplementary material available at https://doi.org/10.1007/s11120-021-00847-x.

Author contributions W. Z. and Y. Y. conceived and designed the research; Y. Y. and K. W. performed the experiments; Y. Y., F. D., and W. Z. wrote the manuscript. All authors contributed to data evaluation and interpretation. All authors read and approved the finalized version of the manuscript.

Funding This work was supported by the National Key Research and Development Program of China (2016YFD0300102). W.Z. was supported by the Innovation Program and the Elite Youth Program of the Chinese Academy of Agricultural Sciences.

\section{Declarations}

Conflict of interest The authors wish to declare no known competing financial interests or personal relationships that have influenced the present work.

Open Access This article is licensed under a Creative Commons Attribution 4.0 International License, which permits use, sharing, adaptation, distribution and reproduction in any medium or format, as long as you give appropriate credit to the original author(s) and the source, provide a link to the Creative Commons licence, and indicate if changes were made. The images or other third party material in this article are included in the article's Creative Commons licence, unless indicated otherwise in a credit line to the material. If material is not included in the article's Creative Commons licence and your intended use is not permitted by statutory regulation or exceeds the permitted use, you will need to obtain permission directly from the copyright holder. To view a copy of this licence, visit http://creativecommons.org/licenses/by/4.0/.

\section{References}

Alton PB (2017) Retrieval of seasonal Rubisco-limited photosynthetic capacity at global FLUXNET sites from hyperspectral satellite remote sensing: impact on carbon modelling. Agric For Meteorol 232:74-88. https://doi.org/10.1016/j.agrformet.2016.08.001

Bernhard BJ, Below FE (2020) Plant population and row spacing effects on corn: phenotypic traits of positive yield-responsive hybrids. Agro J 112:1589-1600. https://doi.org/10.1002/agj2. 20206

Biscoe PV, Scott RK, Monteith JL (1975) Barley and its environment. III. carbon budget of the stand. J Appl Ecol 12:269-293. https:// doi.org/10.2307/2401733

Björn LO, Papageorgiou GC, Blankenship RE, Govindjee (2009) A viewpoint: why chlorophyll $a$ ? Photosynth Res 99:85-98. https:// doi.org/10.1007/s11120-008-9395-x 
Boomsma CR, Santini JB, Tollenaar M, Vyn TJ (2009) Maize morphophysiological responses to intense crowding and low nitrogen availability: an analysis and review. Agron J 101:1426-1452. https://doi.org/10.2134/agronj2009.0082

Brenda LG, Lucas B, Maria EO (2006) Source-sink relations and kernel weight differences in maize temperate hybrids. Field Crop Res 95:316-326. https://doi.org/10.1016/j.fcr.2005.04.002

Carmo-Silva E, Andralojc PJ, Scales JC, Driever SM, Mead A, Lawson T, Raines CA, Parry MAJ (2017) Phenotyping of field-grown wheat in the UK highlights contribution of light response of photosynthesis and flag leaf longevity to grain yield. J Exp Bot 68:3473-3486. https://doi.org/10.1093/jxb/erx169

Corrêa FF, Pereira MP, Madail RH, Santos BR, Barbosa S, Castro EM, Pereira FJ (2017) Anatomical traits related to stress in high density populations of Typha angustifolia L. (Typhaceae). Braz J Biol 77:52-59. https://doi.org/10.1590/1519-6984.09715

Chytyk C, Hucl P, Gray G (2011) Leaf photosynthetic properties and biomass accumulation of selected western Canadian spring wheat cultivars. Can J Plant Sci 91:305-314. https://doi.org/10.4141/ CJPS09163

Curin F, Severini AD, González FG, Otegui ME (2020) Water and radiation use efficiencies in maize: breeding effects on singlecross Argentine hybrids released between 1980 and 2012. Field Crop Res 246:107683. https://doi.org/10.1016/j.fcr.2019.107683

Ding L, Wang KJ, Jiang GM, Li YG, Jiang CD, Liu MZ, Niu SL, Peng Y (2006) Diurnal variation of gas exchange, chlorophyll fluorescence, and xanthophyll cycle components of maize hybrids released in different years. Photosynthetica 44:26-31. https://doi. org/10.1007/s11099-005-0154-3

Driever SM, Lawson T, Andralojc PJ, Raines CA, Parry MA (2014) Natural variation in photosynthetic capacity, growth, and yield in 64 field-grown wheat genotypes. J Exp Bot 65:4959-4973. https:// doi.org/10.1093/jxb/eru253

Echarte L, Luque S, Andrade FH, Sadras VO, Cirilo A, Otegui ME, Vega CRC (2000) Response of maize kernel number to plant density in Argentinean hybrids released between 1965 and 1993. Field Crop Res 68:1-8. https://doi.org/10.1016/S0378-4290(00) 00101-5

Evans JR, Lawson T (2020) From green to gold: agricultural revolution for food security. J Exp Bot 71:2211-2215. https://doi.org/ 10.1093/jxb/eraa110

Fang XM, Li YS, Nie J, Wang C, Huang KH, Zhang YK, Zhang YL, She HZ, Liu XB, Ruan RW, Yuan XH, Yi ZL (2018) Effects of nitrogen fertilizer and planting density on the leaf photosynthetic characteristics, agronomic traits and grain yield in common buckwheat (Fagopyrum esculentum M.). Field Crop Res 219:160-168. https://doi.org/10.1016/j.fcr.2018.02.001

FAO (2017) FAOSTAT-Agriculture Database. http://www.fao.org/faost at/en/\#home

Foley JA, Ramankutty N, Brauman KA, Cassidy ES, Gerber JS, Johnston M, Mueller ND, O'Connell C, Ray DK, West PC, Balzer C, Bennett EM, Carpenter SR, Hill J, Monfreda C, Polasky S, Rockstrom J, Sheehan J, Siebert S, Tilman D, Zaks DP (2011) Solutions for a cultivated planet. Nature 478:337-342. https://doi. org/10.1038/nature 10452

Gai Z, Zhang J, Li C (2017) Effects of starter nitrogen fertilizer on soybean root activity, leaf photosynthesis and grain yield. PLoS ONE 12:e174841. https://doi.org/10.1371/journal.pone.0174841

Ghimire B, Timsina D, Nepal J (2015) Analysis of chlorophyll content and its correlation with yield attributing traits on early varieties of maize (Zea mays L.). J Maize Res Dev 1:134-145. https://doi. org/10.5281/zenodo.34263

Gitelson AA, Vina A, Masek JG, Verma SB, Suyker AE (2008) Synoptic monitoring of gross primary productivity of maize using Landsat data. IEEE Geosci Remote Sens Lett 5:133-137. https:// doi.org/10.1109/LGRS.2008.915598
Gong F, Wu X, Zhang H, Chen Y, Wang W (2015) Making better maize plants for sustainable grain production in a changing climate. Front Plant Sci 6:835. https://doi.org/10.3389/fpls.2015.00835

Holalu SV, Finlayson SA (2017) The ratio of red light to far red light alters Arabidopsis axillary bud growth and abscisic acid signalling before stem auxin changes. J Exp Bot 68:943-952. https://doi.org/ 10.1093/jxb/erw479

Hou P, Liu Y, Liu WM, Liu GZ, Xie RZ, Wang KR, Ming B et al (2020) How to increase maize production without extra nitrogen input. Resour Conserv Recycl 160:104913. https://doi.org/10. 1016/j.resconrec.2020.104913

Janečková H, Husičková A, Lazár D, Ferretti U, Pospíšil P, Špundová M (2019) Exogenous application of cytokinin during dark senescence eliminates the acceleration of photosystem II impairment caused by chlorophyll $b$ deficiency in barley. Plant Physiol Biochem 136:43-51. https://doi.org/10.1016/j.plaphy. 2019.01.005

Kume A, Akitsu T, Nasahara KN (2018) Why is chlorophyll $b$ only used in light-harvesting systems? J Plant Res 131:961-972. https://doi.org/10.1007/s10265-018-1052-7

Kusaba M, Tanaka A, Tanaka R (2013) Stay-green plants: what do they tell us about the molecular mechanism of leaf senescence. Photosynth Res 117:221-234. https://doi.org/10.1007/ s11120-013-9862-x

Leakey AD, Ferguson JN, Pignon CP, Wu A, Jin Z, Hammer GL, Lobell DB (2019) Water use efficiency as a constraint and target for improving the resilience and productivity of $\mathrm{C}_{3}$ and $\mathrm{C}_{4}$ crops. Annu Rev Plant Biol 70:78-808. https://doi.org/10.1146/annur ev-arplant-042817-040305

Li CF, Tao ZQ, Liu P, Zhang JW, Zhuang KZ, Dong ST, Zhao M (2015) Increased grain yield with improved photosynthetic characters in modern maize parental lines. J Integr Agric 14:17351744. https://doi.org/10.1016/S2095-3119(14)60959-X

Li X, Zhang G, Sun B, Zhang S, Zhang Y, Liao Y, Zhou Y, Xia X, Shi K, Yu J (2013) Stimulated leaf dark respiration in tomato in an elevated carbon dioxide atmosphere. Sci Rep 3:1-8. https://doi. org/10.1038/srep03433

Li X, Wang P, Li J, Wei S, Yan Y, Yang J, Zhao M, Langdale JA, Zhou W (2020) Maize GOLDEN2-LIKE genes enhance biomass and grain yields in rice by improving photosynthesis and reducing photoinhibition. Commun Biol 3:1-12. https://doi.org/10.1038/ s42003-020-0887-3

Lichtenthaler HK (1987) Chlorolphylls and carotenoids: pigments of photosynthetic biomembranes. Method Enzymol 148:350-382. https://doi.org/10.1016/0076-6879(87)48036-1

Liu G, Hou P, Xie R, Ming B, Wang K, Xu W, Liu W, Yang Y, Li $S$ (2017) Canopy characteristics of high-yield maize with yield potential of $22.5 \mathrm{Mg} \mathrm{ha}^{-1}$. Field Crop Res 213:221-230. https:// doi.org/10.1016/j.fcr.2017.08.011

Liu GZ, Liu WM, Yang YS, Guo XX, Zhang GQ, Li J, Xie RZ, Ming B, Wang KR, Hou P, Li SK (2020) Marginal superiority of maizean indicator for density tolerance under high plant density. Sci Rep 10:1-6. https://doi.org/10.1038/s41598-020-72435-3

Long SP, Zhu XG, Naidu SL, Ort DR (2006) Can improvement in photosynthesis increase crop yields? Plant, Cell Environ 29:315-330. https://doi.org/10.1111/j.1365-3040.2005.01493.x

Long SP, Marshall CA, Zhu XG (2015) Meeting the global food demand of the future by engineering crop photosynthesis and yield potential. Cell 161:56-66. https://doi.org/10.1016/j.cell. 2015.03.019

Lu CQ, Tian HQ (2017) Global nitrogen and phosphorus fertilizer use for agriculture production in the past half century: shifted hot spots and nutrient imbalance. Earth Syst Sci Data 9:181-192. https://doi.org/10.5194/essd-9-181-2017

Luo X, Croft H, Chen JM, He L, Keenan TF (2019) Improved estimates of global terrestrial photosynthesis using information on 
leaf chlorophyll content. Glob Change Biol 25:2499-2514. https:// doi.org/10.1111/gcb. 14624

Mansfield BD, Mumm RH (2014) Survey of plant density tolerance in U.S. maize germplasm. Crop Sci 54:157-173. https://doi.org/10. 2135/cropsci2013.04.0252

Mastrodomenico AT, Haegele JW, Seebauer JR, Below FE (2018) Yield stability differs in commercial maize hybrids in response to changes in plant density, nitrogen fertility, and environment. Crop Sci 58:230-241. https://doi.org/10.2135/cropsci2017.06.0340

Meena RK, Reddy KS, Gautam R, Maddela S, Reddy AR, Gudipalli P (2021) Improved photosynthetic characteristics correlated with enhanced biomass in a heterotic F1 hybrid of maize (Zea mays L.). Photosynth Res 147:253-267. https://doi.org/10.1007/ s11120-021-00822-6

Ming B, Xie RZ, Hou P, Li LL, Wang KR, Li SK (2017) Changes of maize planting density in China. Sci Agric Sin 50:1960-1972

Niu L, Yan Y, Hou P, Bai W, Zhao R, Wang Y, Li S, Du T, Zhao M, Song J, Zhou W (2020) Influence of plastic film mulching and planting density on yield, leaf anatomy, and root characteristics of maize on the Loess Plateau. Crop J 8:548-564. https://doi.org/ 10.1016/j.cj.2019.12.002

Niu XK, Xie RZ, Liu X, Zhang FL, Li SK, Gao SJ (2013) Maize yield gains in Northeast China in the last six decades. J Integr Agric 12:630-637. https://doi.org/10.1016/S2095-3119(13)60281-6

Ort DR, Long SP (2014) Limits on yields in the Corn Belt. Science 344:484-485. https://doi.org/10.1126/science. 1253884

Parry MAJ, Reynolds M, Salvucci ME, Raines C, Andralojc PJ, Zhu XG, Price GD, Condon AG, Furbank RT (2011) Raising yield potential of wheat. II. Increasing photosynthetic capacity and efficiency. J Exp Bot 62:453-467. https://doi.org/10.1093/jxb/erq304

Paz DB, Henderson K, Loreau M (2020) Agricultural land use and the sustainability of social-ecological systems. Ecol Model 437:109312. https://doi.org/10.1016/j.ecolmodel.2020.109312

Peng S, Krieg DR, Girma FS (1991) Leaf photosynthetic rate is correlated with biomass and grain production in grain sorghum lines. Photosynth Res 28:1-7. https://doi.org/10.1007/BF00027171

Phalan B, Onial M, Balmford A, Green RE (2011) Reconciling food production and biodiversity conservation: land sharing and land sparing compared. Science 333:1289-1291. https://doi.org/10. $1126 /$ science. 1208742

Postma JA, Hecht VL, Hikosaka K, Nord EA, Pons TL, Poorter H (2021) Dividing the pie: a quantitative review on plant density responses. Plant, Cell Environ 44:1072-1094. https://doi.org/10. 1111/pce. 13968

Pradhan P, Fischer G, van Velthuizen H, Reusser DE, Kropp JP (2015) Closing yield gaps: how sustainable can we be? PLoS ONE 10:e0129487. https://doi.org/10.1371/journal.pone.0129487

Raines CA (2011) Increasing photosynthetic carbon assimilation in $\mathrm{C}_{3}$ plants to improve crop yield: current and future strategies. Plant Physiol 155:36-42. https://doi.org/10.1104/pp.110.168559

Ray DK, Ramankutty N, Mueller ND, West PC, Foley JA (2012) Recent patterns of crop yield growth and stagnation. Nat Commun 3:1-7. https://doi.org/10.1038/ncomms2296

Ray DK, Mueller ND, West PC, Foley JA (2013) Yield trends are insufficient to double global crop production by 2050 . PLoS ONE 8:e66428. https://doi.org/10.1371/journal.pone.0066428

Ren BZ, Cui HY, Camberato JJ, Dong ST, Liu P, Zhao B, Zhang JW (2016) Effects of shading on the photosynthetic characteristics and mesophyll cell ultrastructure of summer maize. Sci Nat 103:1-12. https://doi.org/10.1007/s00114-016-1392-x

Reynolds MP, Delgado MI, Gutierrez-Rodriguez M, Larque-Saavedra A (2000) Photosynthesis of wheat in a warm, irrigated environment: I: genetic diversity and crop productivity. Field Crop Res 66:37-50. https://doi.org/10.1016/S0378-4290(99)00077-5
Sadras VO, Lawson C, Montoro A (2012) Photosynthetic traits in Australian wheat varieties released between 1958 and 2007. Field Crop Res 134:19-29. https://doi.org/10.1016/j.fcr.2012.04.012

Sher A, Khan A, Cai LJ, Ahmad MI, Asharf U, Jamoro SA (2017) Response of maize grown under high plant density; performance, issues and management - a critical review. Adv Crop Sci Technol 5:275. https://doi.org/10.4172/2329-8863.1000275

Sinclair TR, Purcell LC, Sneller CH (2004) Crop transformation and the challenge to increase yield potential. Trends Plant Sci 9:70-75. https://doi.org/10.1016/j.tplants.2003.12.008

Sinclair TR, Rufty TW, Lewis RS (2019) Increasing photosynthesis: unlikely solution for world food problem. Trends Plant Sci 24:1032-1039. https://doi.org/10.1016/j.tplants.2019.07.008

Slattery RA, Ainsworth EA, Ort DR (2013) A meta-analysis of responses of canopy photosynthetic conversion efficiency to environmental factors reveals major causes of yield gap. J Exp Bot 64:3723-3733. https://doi.org/10.1093/jxb/ert207

Stockel J, Oelmuller R (2004) A novel protein for photosystem I biogenesis. J Biol Chem 279:10243-10251. https://doi.org/10. 1074/jbc.M309246200

Testa G, Reyneri A, Blandino M (2016) Maize grain yield enhancement through high plant density cultivation with different interrow and intra-row spacings. Eur J Agron 72:28-37. https://doi. org/10.1016/j.eja.2015.09.006

Tollenaar M (1989) Genetic improvement in grain yield of commercial maize hybrids grown in Ontario from 1959 to 1988 . Crop Sci 29:1365-1371. https://doi.org/10.2135/cropsci1989.00111 83 X002900060007x

van Ittersum MK, Cassman KG (2013) Yield gap analysis-rationale, methods and applications-introduction to the special issue. Field Crop Res 143:1-3. https://doi.org/10.1016/j.fcr.2012.12.012

Vietor DM, Musgrave RB (1979) Photosynthetic selection of Zea mays L. III. The relationship between $\mathrm{CO}_{2}$ exchange and dry matter accumulation of two hybrids. Crop Sci 19:70-75. https:// doi.org/10.2135/cropsci1979.0011183X001900010016x

Wang B, Li Z, Ran Q, Li P, Peng Z, Zhang J (2018) ZmNF-YB16 overexpression improves drought resistance and yield by enhancing photosynthesis and the antioxidant capacity of maize plants. Front Plant Sci 9:709. https://doi.org/10.3389/fpls.2018. 00709

Wei S, Wang X, Zhu Q, Jiang D, Dong S (2017) Optimising yield and resource utilisation of summer maize under the conditions of increasing density and reducing nitrogen fertilization. Sci Nat 104:86. https://doi.org/10.1007/s00114-017-1509-x

Wei S, Wang X, Li G, Jiang D, Dong S (2019) Maize canopy apparent photosynthesis and ${ }^{13} \mathrm{C}$-photosynthate reallocation in response to different density and $\mathrm{N}$ rate combinations. Front Plant Sci 10:1113. https://doi.org/10.3389/fpls.2019.01113

Wei H, Kong D, Yang J, Wang H (2020) Light regulation of stomatal development and patterning: shifting the paradigm from Arabidopsis to grasses. Plant Commun 1:100030. https://doi.org/10. 1016/j.xplc.2020.100030

Wells R, Schulze LL, Ashley DA, Boerma HR, Brown RH (1982) Cultivar differences in canopy apparent photosynthesis and their relationship to seed yield in soybeans. Crop Sci 22:886-890. https://doi.org/10.2135/cropsci1982.0011183X002200040044x

Wu A, Doherty A, Farquhar GD, Hammer GL (2018) Simulating daily field crop canopy photosynthesis: an integrated software package. Funct Plant Biol 45:362-377. https://doi.org/10.1071/ FP17225

Wu A, Hammer GL, Doherty A, von Caemmerer S, Farquhar GD (2019) Quantifying impacts of enhancing photosynthesis on crop yield. Nat Plants 5:380-388. https://doi.org/10.1038/ s41477-019-0398-8

Xu W, Liu C, Wang K, Xie R, Ming B, Wang Y, Zhang G, Liu G, Zhao R, Fan P, Li S, Hou P (2017) Adjusting maize plant density to 
different climatic conditions across a large longitudinal distance in China. Field Crops Res 212:126-134. https://doi.org/10.1016/j. fcr.2017.05.006

Yamazaki JY (2010) Is light quality involved in the regulation of the photosynthetic apparatus in attached rice leaves? Photosynth Res 105:63-71. https://doi.org/10.1007/s11120-010-9567-3

Yan P, Pan JX, Zhang WJ, Shi JF, Chen XP, Cui ZL (2017) A high plant density reduces the ability of maize to use soil nitrogen. PLoS ONE 12:e172717. https://doi.org/10.1371/journal.pone. 0172717

Yang Y, Xu W, Hou P, Liu G, Liu W, Wang Y, Zhao R, Ming B, Xie R, Wang K, Li S (2019) Improving maize grain yield by matching maize growth and solar radiation. Sci Rep 9:1-11. https://doi.org/ 10.1038/s41598-019-40081-z

Yang YS, Guo XX, Hou P, Xue J, Liu GZ, Liu WM, Wang YH, Zhao RL, Ming B, Xie RZ, Wang KR, Li SK (2020) Quantitative effects of solar radiation on maize lodging resistance mechanical properties. Field Crop Res 255:107906. https://doi.org/10.1016/j.fcr. 2020.107906

Zelitch I (1982) The close relationship between net photosynthesis and crop yield. Bioscience 32:796-802. https://doi.org/10.2307/ 1308973

Zhang DS, Zhang LZ, Liu JG, Han S, Wang Q, Evers J, Liu J, van der Werf W, Li L (2014) Plant density affects light interception and yield in cotton grown as companion crop in young jujube plantations. Field Crops Res 169:132-139. https://doi.org/10.1016/j.fcr. 2014.09.001

Zhang DS, Sun ZS, Feng LS, Bai W, Yang N, Zhang Z, Du GJ, Feng C, Cai Q, Wang Q, Zhang Y, Wang RN, Arshad A, Hao XY,
Sun M, Gao ZQ, Zhang LZ (2020) Maize plant density affects yield, growth and source-sink relationship of crops in maize/peanut intercropping. Field Crop Res 257:107926. https://doi.org/10. 1016/j.fcr.2020.107926

Zhang LX, Qiang H, Li SQ, Chen XL (2011) Impact of atmospheric ammonia on growth, $\mathrm{C}$ and $\mathrm{N}$ accumulation and photosynthesis of two maize cultivars with different $\mathrm{N}$ root supply. Plant Soil Environ 57:11-18. https://doi.org/10.17221/6/2010-PSE

Zhang J (2011) China's success in increasing per capita food production. J Exp Bot 62:3707-3711. https://doi.org/10.1093/jxb/err132

Zhang Y, Gu WL, Dai JY (1992) Effect of low temperature on photosynthesis, superoxide dismutase activity and kernel yield in maize. Acta Agron Sin 18:397-400

Zheng YP, Xu M, Hou RX, Shen RC, Qiu S, Ouyang Z (2013) Effects of experimental warming on stomatal traits in leaves of maize (Zea may L.). Ecol Evol 3:3095-3111. https://doi.org/10.1002/ ece3.674

Zhu J, Vos J, van der Werf W, van der Putten PE, Evers JB (2014) Early competition shapes maize whole-plant development in mixed stands. J Exp Bot 65:641-653. https://doi.org/10.1093/jxb/ert408

Zhu XG, Long SP, Ort DR (2010) Improving photosynthetic efficiency for greater yield. Annu Rev Plant Biol 61:235-261. https://doi. org/10.1146/annurev-arplant-042809-112206

Publisher's Note Springer Nature remains neutral with regard to jurisdictional claims in published maps and institutional affiliations. 